\title{
Tube morphology, ultrastructures and mineralogy in recent Spirorbinae (Annelida: Polychaeta: Serpulidae). II. Tribe Spirorbini
}

\author{
A.P. Ippolitov ${ }^{1}$, A.V. Rzhavsky² \\ ${ }^{I}$ Geological Institute of Russian Academy of Sciences (GIN RAS), 7 Pyzhevskiy per., Moscow, \\ Russia, 119017,e-mail: ippolitov.ap@gmail.com \\ ${ }^{2}$ A.N. Severtsov Institute of Ecology and Evolution of Russian Academy of Sciences (IPEE RAS), 33 \\ Leninskiy prosp., Moscow, Russia, 119071,e-mail:rzhavskij@mail.ru
}

ABSTRACT: This is the second paper of the series started with Ippolitov and Rzhavsky (2014) providing detailed descriptions of recent spirorbin tubes, their mineralogy and ultrastructures. Here we describe species of the tribe Spirorbini Chamberlin, 1919 that includes a single genus Spirorbis Daudin, 1800. Tube ultrastructures found in the tribe are represented by two types - irregularly oriented prismatic (IOP) structure forming the thick main layer of the tube and in some species spherulitic prismatic (SPHP) structure forming an outer layer and, sometimes, inner. Mineralogically tubes are either calcitic or predominantly aragonitic. Correlations of morphological, ultrastructural, and mineralogical characters are discussed. All studied members of Spirorbini can be organized into three groups that are defined by both tube characters and biogeographical patterns and thus, likely correspond to three phylogenetic clades within Spirorbini.

How to cite this article: Ippolitov A.P., Rzhavsky A.V. 2015. Tube morphology, ultrastructures and mineralogy in recent Spirorbinae (Annelida: Polychaeta: Serpulidae). II. Tribe Spirorbini // Invert. Zool. Vol.12. No.1. P.61-92.

KEY WORDS: Tube ultrastructures, tube morphology, tube mineralogy, scanning electron microscopy, X-ray diffraction analysis, Spirorbinae, Spirorbini.

\section{Морфология, ультраструктуры и минералогия трубок современных Spirorbinae (Annelida: Polychaeta: Serpulidae). II. Триба Spirorbini}

\author{
А.П. Ипполитов ${ }^{1}$, А.В. Ржавский ${ }^{2}$ \\ ${ }^{1}$ Геологический институт РАН, Пыжевский пер. 7, Москва, Россия, 119017, e-таil: \\ ippolitov.ap@gmail.com \\ ${ }^{2}$ Институт проблем экологии и эволюиии им. А.Н. Севериова РАН, Ленинский пр. 33, Москва, \\ Poccuя, 119071,e-mail: rzhavskij@mail.ru \\ PЕЗЮМЕ: Эта статья - вторая часть серии (первая часть - см. Ippolitov, Rzhavsky, \\ 2014), посвящённой описанию морфологии, минералогии и ультраструктур трубок \\ современных спирорбин. В статье описываются виды, относящиеся к трибе Spirorbini \\ Chamberlin, 1919, в состав которой входит единственный род Spirorbis Daudin, 1800. \\ Установлено, что ультраструктуры трубок представлены двумя типами: структурой \\ хаотически ориентированных призматических кристаллов, обычно слагающей
}


массивный основной слой трубки, и сферулитовой структурой, слагающей у части видов тонкий приповерхностный слой, а у одного вида и внутренний слой. Минералогически трубки изученных видов могут быть разделены на кальцитовые и преимущественно арагонитовые. Обсуждаются корреляции морфологических, ультраструктурных и минералогических характеристик. Изученные виды трибы могут быть разделены на три группы по характеристикам трубок и особенностям зоогеографического распространения и, таким образом, могут соответствовать отдельным кладам.

Как цитировать эту статью: Ippolitov A.P., Rzhavsky A.V. 2015. Tube morphology, ultrastructures and mineralogy in recent Spirorbinae (Annelida: Polychaeta: Serpulidae). II. Tribe Spirorbini // Invert. Zool. Vol.12. No.1. P.61-92.

КЛЮЧЕВЫЕ СЛОВА: Ультраструктура трубок, морфология трубок, минералогия трубок, сканирующая электронная микроскопия, рентгенодифракционный анализ, Spirorbinae, Spirorbini.

\section{Introduction}

Introductory remarks, including the key terminology of tubes and their ultrastructures, can be found in Ippolitov and Rzhavsky (2014).

\section{Material and methods}

Detailed information on material and methods of the study is provided in Ippolitov and Rzhavsky (2014). Current investigation covers 11 out of 15 known species belonging to the genus Spirorbis of the tribe Spirorbini. All examined materials are from the collection of A.V. Rzhavsky deposited in A. N. Severtsov Institute of Ecology and Evolution, Russian Academy of Sciences, Moscow (IPEE RAS).

\section{Results}

\section{Tribe Spirorbini Chamberlin, 1919}

Diagnosis. The egg-string is incubated inside the parent's tube, being attached posteriorly by a thread to inner tube wall; accordingly, the only type of operculum throughout life time is an endplate with a talon. Other important features are: 1) thoracic uncini rasp-shaped, with 3-4 (5-6 in smallest uncini) longitudinal rows of teeth and usually blunt anterior peg; 2) abdominal uncini distributed fairly symmetrically on both sides of the body; 3 ) abdominal chaetae are flat geniculate, pennant-shaped (blade width decreases gradually towards tip), usually with a thick projecting heel; the length of their blade is no longer than blade length of largest collar chaetae; 4) abdominal capillary hooked chaetae usually appearing on last abdominal chaetigers; 5) larvae have a single white abdominal attachment gland.

Distribution. Most species of Spirorbini can be divided into two distinct biogeographic groups. Representatives of the first group are known from boreal and subtropical waters of Atlantic (mainly of European coasts) and also may reach Atlantic sector of the Arctic (KnightJones P. et al., 1991). Members of the second group are distributed over Pacific coast of North America from boreal/subtropical to tropical zone (Knight-Jones P. et al., 1979). Two species belonging to the latter group (Spirorbis (Spirorbis) bidentatus Bailey et Harris, 1968 and Spirorbis (Spirorbis) marioni Caullery et Mesnil, 1897) are also recorded off islands and archipelagos located in tropical and subtropical belts of both hemispheres in the Pacific and Atlantic (KnightJones P. et al., 1979). The former species was also recorded from New Zealand (Vine, 1977) and the latter is known from Australia, Japan, and Mediterranean (Knight-Jones P., KnightJones E.W., 1995). According to some authors (e.g. Knight-Jones E.W., Knight-Jones P., 1980; Bianchi, 1981; Zibrowius, Bianchi, 1981; Knight-Jones P. et al., 1991) S. (S.) marioni originated from East Pacific and was distributed over the world by ships. In our opinion, the distribution pattern of Spirorbis (S.) bidentatus may be explained in a similar way. 
Three species of Spirorbis are restricted to their type localities in subtropical or tropical waters and cannot be placed with certainty into any of the above biogeographic groups. These are Spirorbis (Spirorbis) infundibulum Harris et Knight-Jones, 1964 (north-eastern coast of Spain, Mediterranean), Spirorbis (Spirorbis) placophora Bailey et Harris, 1968 (Galapagos Islands, East Pacific), and Spirorbis (Velorbis) gesae Knight-Jones et Knight-Jones, 1995 (Madeira, North-East Atlantic).

Remarks. The tribe includes only the genus Spirorbis Daudin, 1800.

\section{Genus Spirorbis Daudin, 1800}

Type species: Serpula spirorbis Linnaeus, 1758.

Diagnosis. Tube usually sinistral (clockwise), but may be dextral (anticlockwise), and several species have both dextral and sinistral tubes; margins of collar and thoracic membranes not fused over thoracic groove (excluding one species, see "Remarks"); large collar chaetae bent, modified fin-and-blade or finand-blade cross-striated; simple limbate and sickle chaetae in $3^{\text {rd }}$ thoracic fascicles; three thoracic chaetigers.

Composition. The genus includes subgenus Spirorbis with 14 recent species (11 are described below) and monotypic subgenus Velorbis Knight-Jones et Knight-Jones, 1995 (not covered in this study).

Distribution. As for the tribe (see above).

Remarks. Species of the subgenus Spirorbis differ from those of the subgenus Velorbis by having free margins of collar and thoracic membranes. The only species of the latter subgenus, $S$. $(V$.) gesae Knight-Jones P. et Knight-Jones E.W., 1995 has margins of collar and thoracic membranes fused over thoracic groove.

Many of recent species originally described as "Spirorbis" have now been attributed to other tribes and genera. Among numerous fossil species recorded as "Spirorbis" many are not annelids at all, while others are of uncertain generic affinity within spirorbins (Ippolitov etal., 2014).

\section{Subgenus Spirorbis Daudin, 1800}

\section{Spirorbis (Spirorbis) bidentatus Bailey et Harris, 1968}

Fig. 1A-H.

For descriptions see Bailey, Harris, 1968, 169-170: Fig. 3c, 8 a-h; Knight-Jones P. et al., 1979: 425, Fig. 2A $(\mathrm{a}-\mathrm{d})$.

Material examined. One specimen was studied with SEM in longitudinal section (IPEE No. 1/2553, Grand Canary, Canary Islands, depth $0-1 \mathrm{~m}$, on stones). External tube morphology and mineralogy were analyzed using specimens and tube fragments from the same sample.

Tube morphology. Tubes are sinistral, planospiral or with overlapping coils (Fig. 1AC); up to $1.5 \mathrm{~mm}$ in whorl diameter; thin-walled, white opaque, non-porcellaneous. The crosssection is somewhat quadrangular: there are usually two indistinct and low longitudinal keels, one towards the periphery and one on the inner edge of the whorl (Fig. 1B,C), in some specimens keels are absent (Fig. 1A). There are also records of three-keeled tubes (see Bailey et Harris, 1968; Vine, 1977).

Tube ultrastructures. Tube wall is composed of a single layer with IOP (irregularly oriented prismatic sensu Vinn et al., 2008) structure, which can be subdivided into three gradually interchanging zones having slightly different crystal appearances (Fig. 1D). The inner zone (Fig. 1G) is 6-7 $\mu \mathrm{m}$ wide (corresponding wall thickness is $60 \mu \mathrm{m}$ ) and composed of densely packed smallest crystals of isometric or elongated form, the latter do not exceed $1 \mu \mathrm{m}$ in length. The widest middle zone (Fig. 1F) is composed of loosely packed acicular crystals $3-4 \mu \mathrm{m}$ in length, $0.5 \mu \mathrm{m}$ in width. Average size of crystals gradually increases towards the outer tube surface. The outer zone (Fig. 1E) underlying outer surface is about $10-15 \mu \mathrm{m}$ wide and progressively consolidated by cement. In the early growth stages $($ Fig. $1 \mathrm{H})$ the wall consists of small $(0.7-1 \mu \mathrm{m})$ isometric crystals densely cemented by amorphous matter. Parabolic growth lamellae indistinct, the parabolic axis is located in the central part of the wall. Inner organic lining is very thin, but its thickness was not established.

Tube mineralogy. 75\% aragonite $\left(\mathrm{I}_{\text {arag }}=9\right)$, $25 \%$ calcite $\left(\mathrm{I}_{\text {calc }}=3\right)$, low reliability of data.

Distribution. Pacific coast of Panama (Knight-Jones P. et al., 1979), Galapagos Is- 


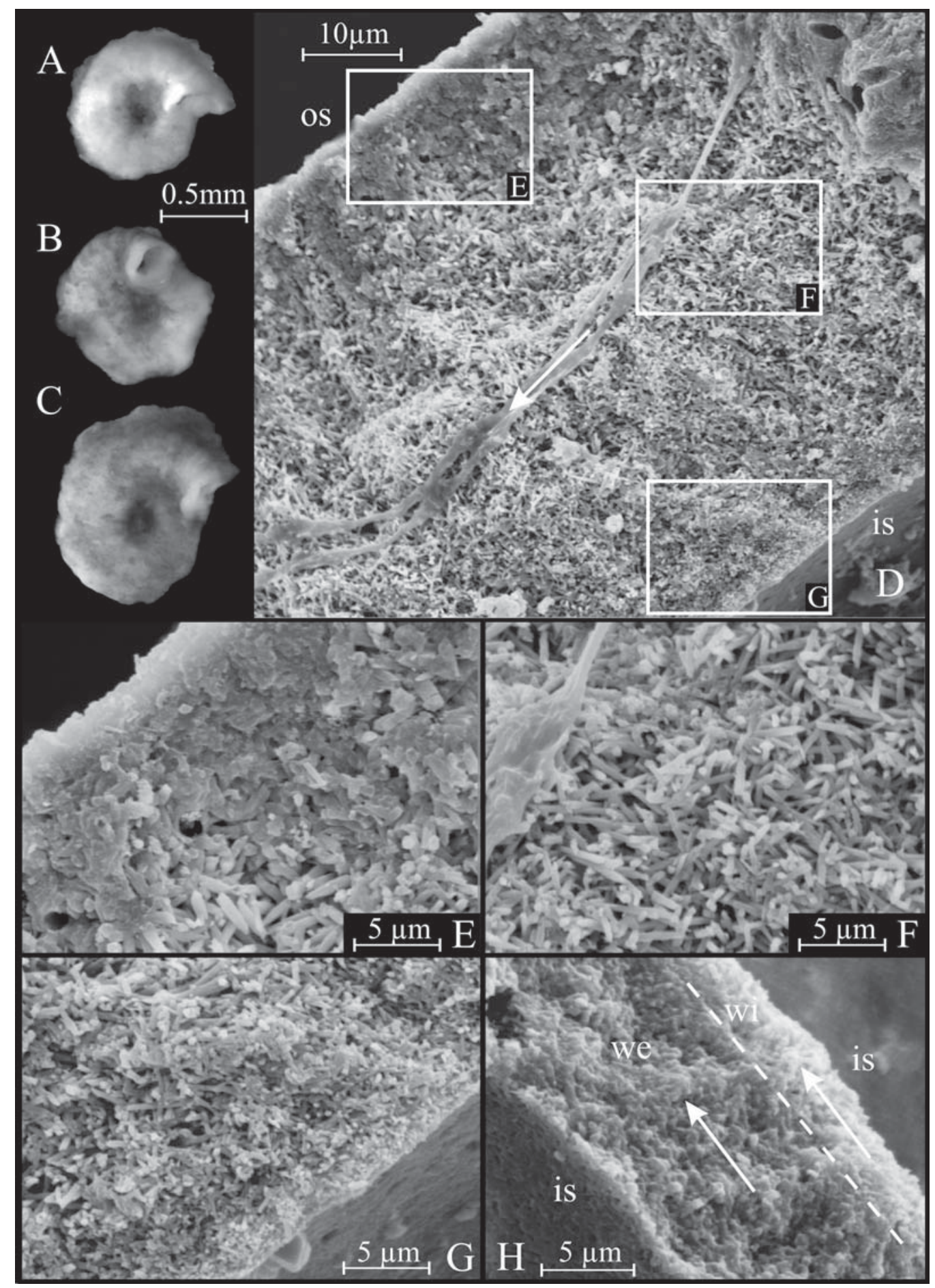


lands (Bailey, Harris, 1968), New Zealand(Vine, 1977), Aruba and St. Eustatius (Caribbean Sea) and Canary Island (Knight-Jones P. et al., 1979).

Ecology. Known intertidally and at depth 50 $\mathrm{m}$, from stones.

Remarks. Our material originates from the collection of P. and E.W. Knight-Joneses from Canary Islands and has tube morphology exactly as they described (Knight-Jones P. et al., 1979). According to description of specimens of Bailey \& Harris (1968) from Galapagos Islands and Vine (1977) from New Zealand, there are not two, but three longitudinal keels.

\section{Spirorbis (Spirorbis) bifurcatus Knight- Jones, 1978}

Fig. 2A-H.

For descriptions see Knight-Jones P., 1978: 203-205, Fig. 1A-J; Knight-Jones P. et al., 1979: 426, Fig. 2B(a-f).

Material examined. Three specimens were studied with SEM in longitudinal sections (IPEE No. 2/2560, aquarium of the Plymouth Marine Laboratory, UK, origin is unknown). Mineralogy was analyzed using the set consisting of a single entire tube accompanied by dispersed fragments from the same sample. The external tube morphology is illustrated using specimens from the same sample and from IPEE No. 1/2510 (Yaduina Head, Oregon, USA, littoral, on stones).

Tube morphology. Tubes are sinistral or dextral; planospiral or with the last whorl coiling over the previous one. Whorl diameter is up to $1.75 \mathrm{~mm}$. Tube walls are thin, white opaque, non-porcellaneous. There are usually two low longitudinal keels (Fig. 2A), one towards the periphery and one on the inner edge of the whorl, making the tube somewhat quadrangular in crosssection. Juveniles may be unsculptured (Fig. 2B).

Tube ultrastructures. Wall is unilayered showing typical IOP structure with loosely lying crystals (Fig. 2C). No clear zonation can be seen from the outer side to inner one. Crystals throughout the wall are 3-4 $\mu \mathrm{m}$ long (locally up to 5-6 $\mu \mathrm{m}$ ) and $0.5-0.75 \mu \mathrm{m}$ wide, and have somewhat pointed ends. Near the inner surface there is a narrow zone with crystals proportionally twice as small than in other parts of the wall (Fig. 2E); they also show consolidation by amorphous matter (Fig. 2F). Near the outer surface crystals tend to be stockier than in the middle part of the wall (Fig. 2D), but they do not form a separate, clearly defined zone. Width of crystals here is up to $2 \mu \mathrm{m}$, length of their long axes is 3-4 $\mu \mathrm{m}$. Details of inner organic lining were not examined.

Tube mineralogy. $80 \%$ aragonite $\left(\mathrm{I}_{\text {arag }}=20\right)$, $20 \%$ calcite $\left(\mathrm{I}_{\text {calc }}=5\right)$, reliability of analysis is average.

Distribution. Pacific coast of North America from Vancouver Island (Canada) to Los Angeles (California, USA) (Knight-Jones P. et al., 1979).

Ecology. Recorded intertidally and from depth of $30 \mathrm{~m}$, from rocks and stones.

Fig. 1. Spirorbis (Spirorbis) bidentatus. A-C - tubes with two vestigial keels forming somewhat quadrangular cross-section: A, C — planospiral; B with overlapping coils; D-H - tube ultrastructures: $\mathrm{D}$ - general view of longitudinal section; $\mathrm{E}$ - outer zone of the wall with distinct consolidation of tube surface by cement; F - middle part of the wall with typical chaotically oriented prismatic crystals forming IOP structure; $\mathrm{G}$ - innermost part of the wall with crystals distinctly smaller near the lumen than elsewhere in the wall; $\mathrm{H}$ - section through the area of coils contact in early growth stages showing large content of amorphous matter and thin wall at the internal side of the coil.

Abbreviations: os - outer surface, is - inner surface, wi - tube wall on the internal side of the last coil, we - tube wall on the external side of the next to last coil. Large arrows indicate the direction of tube growth.

Рис. 1. Spirorbis (Spirorbis) bidentatus. А-C - трубки с двумя зачаточными килями, придающими поперечному сечению слегка квадратную форму: А, C - планоспиральные; В - с налегающими последними оборотами; D-H - ультраструктуры трубок: D — общий вид стенки в продольном сечении; E - наружная часть стенки, хорошо заметна консолидация поверхности бесструктурным органическим веществом; F — средняя часть стенки с типичной структурой хаотически ориентированных призматических кристаллов; $\mathrm{G}$ - внутренняя часть стенки, характеризующаяся существенно меньшими размерами кристаллов возле полости трубки; Н - продольное сечение через смыкание оборотов на ранних стадиях роста с высоким содержанием цемента и очень тонкой внутренней стенкой позднего оборота.

Условные обозначения: os - наружная поверхность, is - внутренняя поверхность, wi - стенка внутренней стороны позднего оборота; we - стенка наружной стороны раннего оборота. Большие стрелки указывают направление роста трубки. 


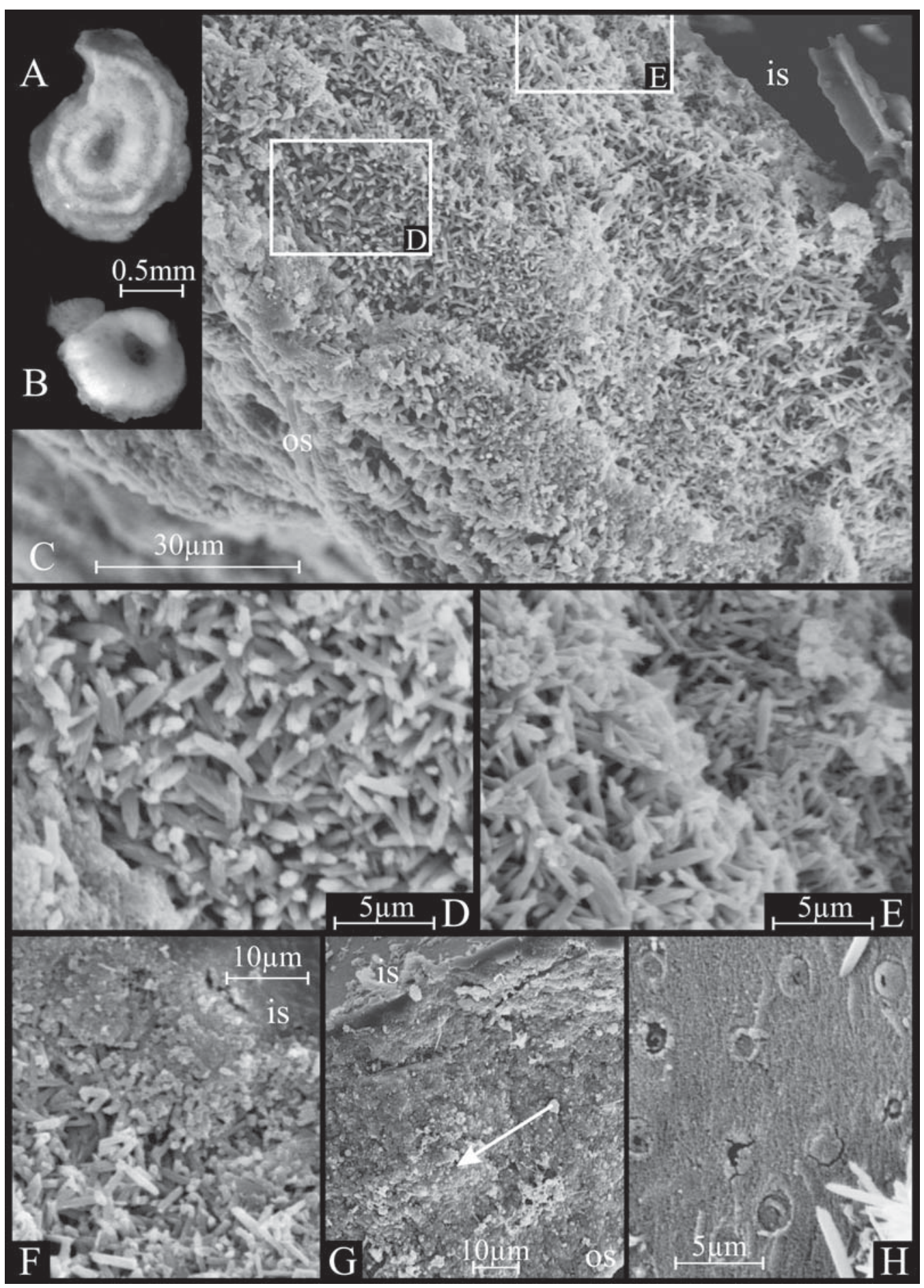


Remarks. All specimens used for SEM analysis were dextral because sinistral tubes available for our study were rare and fragmented. The description above is provided for a section made along the upper side of the tube. Two additional specimens were studied in standard longitudinal sections. One of them has demonstrated the same ultrastructure as described above, but the second has demonstrated a high content of cement totally hiding the appearance of crystals (Fig. 2G). Inner surface of the tube in this untypical specimen has strange numerous nipple-like formations: small protuberances on the tube wall $(2-2.5 \mu \mathrm{m}$ in diameter), each having a central pore and disrupting inner organic lining (Fig. 2H). The functions of these lumps are unclear.

\section{Spirorbis (Spirorbis) corallinae de Silva et Knight-Jones, 1962}

Fig. 3A-H.

For descriptions see de Silva, Knight-Jones E.W., 1962: 602, fig. 1I-L; Knight-Jones P., Knight-Jones E.W., 1977: 461-463, Fig. 3A-K; Rzhavsky et al., 2014: 134136, Fig. 33A-I.

Material examined. Two specimens were studied with SEM in longitudinal sections (IPEE No 2/2560, Oxwich Bay, Bristol Bay, UK, littoral, on Corallina officinalis Linnaeus, 1758). Mineralogy was analyzed using a set of 10 tubes from the same sample. External tube morphology was illustrated using specimens from the same sample.
Tube morphology. Tubes are sinistral, unsculptured, planospiral or with overlapping whorls (Fig. 3A-C); adults rarely exceed 1.5 $\mathrm{mm}$ in coil diameter. Tube walls white opaque, porcellaneous, but in live specimens orange body may be visible through thin walls of initial coils giving an impression of light pinkish colour.

Tube ultrastructures. Wall is two-layered, consisting of a thicker main layer covering the outer one in the early coils; later coils are unilayered. Main layer is represented by a typical IOP structure (Fig. 3D, F); crystals are extremely small $(1-1.5$, rarely $2 \mu \mathrm{m}$ long; 0.5 $\mu \mathrm{m}$ wide), with blunt ends. The form of crystals is often not visible clearly, as they are densely cemented together by amorphous matter. Near the inner surface the content of cement is also significantly higher than in the middle and outer parts of the wall (Fig. 3E). In early coils appearance of crystals remains almost the same, while the quantity of cement is larger (Fig. 3G). Outer covering layer having SPHP (spherulitic prismatic sensu Vinn et al., 2008) structure was detected only in external wall of early coils (Fig. $3 \mathrm{H})$. This layer is $6-8 \mu \mathrm{m}$ thick and constitutes $\sim 1 / 4$ of the total wall width. Longitudinal sections of external wall at the last whorl of the same specimen have not shown any traces of SPHP layer. Crystals underlying outer SPHP layer are arranged more or less parallel to the tube wall. Inner organic lining is thin, up to 0.5 $\mu \mathrm{m}$ thick.

Fig. 2. Spirorbis (Spirorbis) bifurcatus. A-B - tubes: A - adult dextral tube with keels modifying crosssection to sub-quadrangular shape (IPEE No. 2/2560); B - juvenile sinistral tube without sculpture (IPEE No. 1/2510); C-F — tube ultrastructures, specimen 1: C - general view of the wall in longitudinal section; $\mathrm{D}$ - details of the outer part of the wall; E - details of the innermost part of the wall with smaller and more elongated crystals near the lumen; $\mathrm{F}$ - the same, showing dense consolidation by cement near the inner tube surface; G-H - tube ultrastructures, specimen 2: G — general view of the wall, showing dense consolidation by cement; $\mathrm{H}$ - internal surface of the lumen with nipple-like structures of unclear nature.

Abbreviations: os - outer surface, is - inner surface. Large arrow indicates the direction of tube growth.

Рис. 2. Spirorbis (Spirorbis) bifurcatus. А-B - трубки: А — правозакрученная трубка взрослой особи с двумя килями, придающими в поперечном сечении слегка квадратную форму (IPEE No. 2/2560); В - левозакрученная трубка ювенильной особи без скульптуры (IPEE No. 1/2510); C-F — ультраструктуры трубок, экземпляр № 1: C - общий вид стенки в продольном сечении; D- наружная часть стенки; E - внутренняя часть стенки, с мелкими и удлинёнными кристаллами близ внутренней поверхности; F — то же самое в другом ракурсе, хорошо заметна цементация кристаллов вблизи внутренней поверхности; G-H — ультраструктуры трубок, экземпляр № 2: G - общий вид продольного сечения стенки с высокой степенью консолидации кристаллов; Н - внутренняя поверхность трубки с сосцевидными структурами неясной природы.

Условные обозначения: os - наружная поверхность, is - внутренняя поверхность. Большие стрелки указывают направление роста трубки. 


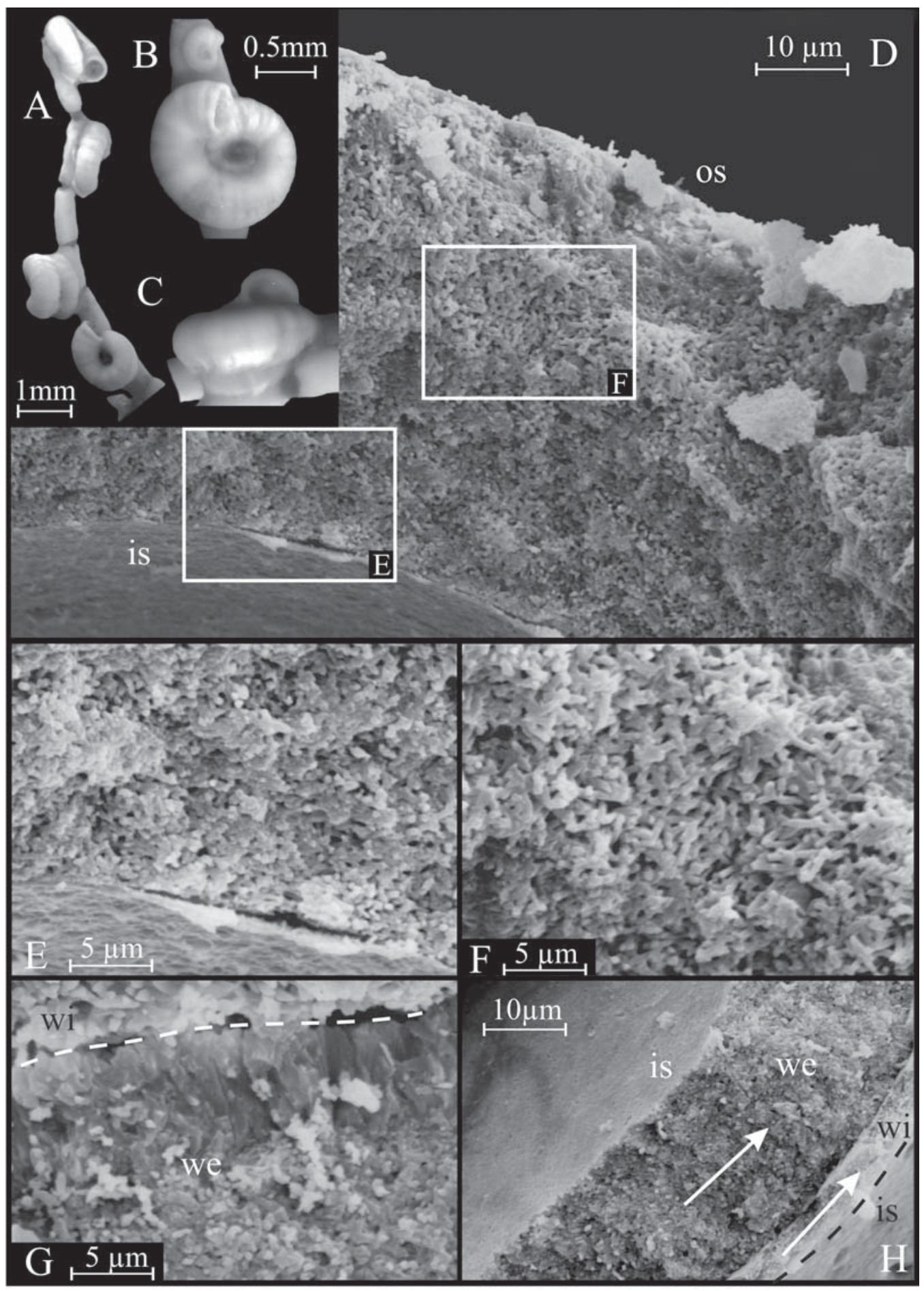


Tube mineralogy. $100 \%$ calcite $\left(\mathrm{I}_{\text {calc }}=181\right)$ with high $\mathrm{Mg}$ content.

Distribution. The species is common in the North-East Atlantic, from the North of Scotland, UK to South Brittany, France (KnightJones P., Knight-Jones E.W., 1977), Ireland (Toner, 1967), and Scilly Islands (Harris, 1968). In the Arctic it is known from the Barents (Rzhavsky, 1992) and Norwegian Seas (KnightJones P. et al., 1991).

Ecology. The species is usually found in tidal pools on red calcareous algae C. officinalis, but may also occupy non-calcareous red algae Chondrus spp. (Knight-Jones P. et KnightJones E.W., 1977).

Remarks. The absence of outer SPHP layer in the last coil does not seem to be an artifact of preservation. The spatial distribution of this layer over the tube surface is not clear, either it is present locally or completely reduced in mature specimens. Internal organic lining viewed from inside of the tube shows numerous indentations of isometric irregular shape $(2-4 \mu \mathrm{m}$ in diameter), probably representing traces of chaetal anchorage on inner side of the tube.

\section{Spirorbis (Spirorbis) cuneatus Gee, 1964} Fig. 4A-G.

For descriptions see Gee, 1964: 412-415, Fig. 4A-H, 5A-D; Knight-Jones P., Knight-Jones E.W., 1977: 466467, Fig. 4L-S.

Material examined. Two specimens were studied with SEM in longitudinal sections (IPEE No. 2/2569,
Aberreiddi Quarry, Welsh, UK, depth 2 m, stones). Mineralogy was analyzed using a set of tubes fragments from another sample (IPEE No. 3/2812, Ibiza, Baleares Islands, Mediterranean Sea). External tube morphology is illustrated using specimens from the same sample as used for mineralogical analysis.

Tube morphology. Tubes are sinistral, planospiral (Fig. 4A), sometimes with the mouth turned upwards from the substrate (Fig. 4B). Whorl diameter is up to $2 \mathrm{~mm}$. Tube walls are white opaque, non-porcellaneous. There are three distinct longitudinal keels not protruding over the mouth. Peripheral attachment flange is present.

Tube ultrastructures. Two studied external walls (Fig. 4C, G) are unilayered with IOP structure, with medium to low cement content. Crystals are 1.5-2 $\mu \mathrm{m}$ long, with corresponding width of $0.5-0.75 \mu \mathrm{m}$ and more or less blunt apexes. Their sizes and shapes vary throughout the wall: inner part (1/3 of the total width) has somewhat smaller crystals and more cement (Fig. 4D), while in the outer part (2/3 of the total width) crystals are stouter (Fig. 4E). However, the typical elongated crystals, common in inner part, are present here, too. Outer surface is consolidated by organic cement (Fig. 4D). Crystals in slightly different sections (i.e., located in the middle and upper parts of the external side) also show some variations of their sizes and shapes within the described ranges. Parabolic growth lamellae are only slightly sloping, the parabolic axis is sub-central, being slightly displaced towards the lumen. Inner organic lining is thin, not exceeding $1 \mu \mathrm{m}$ in thickness.

Fig. 3. Spirorbis (Spirorbis) corallinae. A-C - tubes: A - group of specimens on red algae Corallina officinalis; B - view from the upper side, adult and juvenile specimens; C - lateral view of an adult specimen with overlapping coils; $\mathrm{D}-\mathrm{G}$ - tube ultrastructures, specimen 1: D - general view of transverse section; E, F - details of different parts of the wall; G - transverse section of the early coil with outer layer of SPHP structure; H - specimen 2, longitudinal section through the area of coil contact in early growth stages showing extremely thin wall on the internal side of the whorl, large amount of cement, and subisometric crystals.

Abbreviations: os - outer surface, is - inner surface, wi - tube wall on the internal side of the last coil, we - tube wall on the external side of the next to last coil. Large arrow indicates the direction of tube growth.

Рис. 3. Spirorbis (Spirorbis) corallinae. А-С - трубки: А - группа особей на красной водоросли Corallina officinalis; В - вид сверху, взрослая и ювенильная особи; С - вид сбоку, взрослая особь с налегающими оборотами; $\mathrm{D}-\mathrm{G}$ - ультраструктуры трубок, экземпляр № 1: D - общий вид стенки в поперечном сечении; E, F - различные участки стенки; $\mathrm{G}$ - поперечное сечение раннего оборота с наружным слоем, имеющим сферулитовую призматическую структуру; Н - экземпляр № 2, продольное сечение через смыкание оборотов на ранних стадиях роста с очень тонкой стенкой на внутренней стороне оборота, обильным цементом и субизометричными кристаллами.

Условные обозначения: os - наружная поверхность, is - внутренняя поверхность, wi - стенка внутренней стороны позднего оборота; we - стенка наружной стороны раннего оборота. Большая стрелка указывает направление роста трубки. 
Tube mineralogy. 65\% aragonite $\left(\mathrm{I}_{\text {arag }}=15\right)$, $35 \%$ calcite $\left(\mathrm{I}_{\text {calc }}=8\right)$; low reliability of data.

Distribution. Atlantic coast of Europe from Ireland and Scotland, UK to Marseille, France; Mediterranean Sea (Knight-Jones P., KnightJones E.W., 1977; Knight-Jones P. et al., 1991).

Ecology. Subtidal up to $100 \mathrm{~m}$ depth, occupies rocks, stones and shells.

\section{Spirorbis (Spirorbis) inornatus L'Hardy et Quievreux, 1962}

$$
\text { Fig. 5A-H. }
$$

For descriptions see L'Hardy, Quievreux, 1962: 2175, fig. 5, 10 (as "Spirorbis (Laeospira) inornatus f. procumbens"); Knight-Jones P., Knight-Jones E.W., 1977: 463464, Fig. 3L-T; Rzhavsky et al., 2014: 136-139, Fig. 34A-H, Pl. 2D.

Material examined. Two specimens were studied with SEM in longitudinal sections (IPEE No. 2/2546, Albertcastle, Welsh, UK, lower intertidal zone, on brown algae). Mineralogy was analyzed using a set of seven tubes from the same sample. External tube morphology is illustrated using specimens from the same sample.

Tube morphology. Tubes are sinistral, unsculptured, usually planospiral (Fig. 5A), rarely whorls are overlapping. Coil diameter is up to 3 $\mathrm{mm}$, rarely more. Tube surface is white opaque, somewhat porcellaneous. Peripheral attachment flange may present.

Tube ultrastructures. Wall is two-layered, consisting of a thicker main layer covered with a thinner outer one. The main layer has typical IOP structure consolidated by some cement (Fig. 5B, D, H). Crystals are 1.5-2 $\mu \mathrm{m}$ long with corresponding width of $0.5-0.75 \mu \mathrm{m}$; their apexes are rounded blunt. Crystal size and shape, as well as quantity of cement, are uniform throughout the wall. Only near the lumen (up to $3 \mu \mathrm{m}$ deep) crystals are some smaller and densely cemented (Fig. 5E). Near the outer side of the wall the quantity of amorphous cement also higher than average. Outer covering layer is extremely thin $(\sim 1 \mu \mathrm{m})$ and has SPHP structure (Fig. 5C). No growth lamellae were observed, and no details of inner organic lining were obtained.

Tube mineralogy. $100 \%$ calcite $\left(\mathrm{I}_{\text {calc }}=277\right)$ with high $\mathrm{Mg}$ content.

Distribution. The species is well known from the British and Irish coasts and Brittany, France (Knight-Jones P., Knight-Jones E.W., 1977). Rzhavsky et al. (2014) recorded this species from the Danish coast of Oresund and from the White, Barents, and Norwegian Seas in the Arctic.

Ecology. The species lives strictly within a narrow bathymetric range from the lower intertidal zone to $2 \mathrm{~m}$ deep, occupying brown and non-calcareous red algae. Knight-Jones P. and Knight-Jones E.W (1977) also suggested that fuci are not a characteristic substrate for this species, though in some locations populations of $S$. (S.) inornatus may replace Spirorbis (Spirorbis) spirorbis Linnaeus, 1758 that is typically found on fuci. New data indicate that $S$. (S.) inornatus may be common on fuci in the White, Barents, and Norwegian Seas (Rzhavsky et al., 2014).

Remarks. Inner organic lining of $S$. (S.) inornatus, like in $S$. ( $S$.) corallinae, has numerous indentations probably reflecting chaetal anchorage (Fig. 5G). The concentration of these indentations seems to be higher on the outer side of the tube than on the upper and inner sides.

The attachment flanges that increase the area of attachment to substrate have IOP structure (Fig. 5F). This type of cementation is different from that typical for serpulid species with well-developed covering layers of SPHP structure (see Tanur et al., 2010).

Fig. 4. Spirorbis (Spirorbis) cuneatus. A-B - tubes: A — planospiral tube; B - tube with mouth turned upwards from the substrate; $\mathrm{C}-\mathrm{E}$ - tube ultrastructures, specimen 1: C - general view of the longitudinal section; D, E - details of the wall parts; F, G - specimen 2, longitudinal sections in different parts of the tube, note variations of cement content.

Abbreviations: os - outer surface, is - inner surface. Large arrow indicates the direction of tube growth.

Рис. 4. Spirorbis (Spirorbis) cuneatus. А-В - трубки: А - планоспиральная; В - с устьем, приподнимающимся над субстратом; C-E - ультраструктуры трубок, экземпляр № 1: С - общий вид стенки в продольном сечении; D, E - различные участки стенки; F, G - экземпляр № 2 , продольные сечения различных участков трубки с различным содержанием цемента.

Условные обозначения: os - наружная поверхность, is - внутренняя поверхность. Большая стрелка указывает направление роста трубки. 


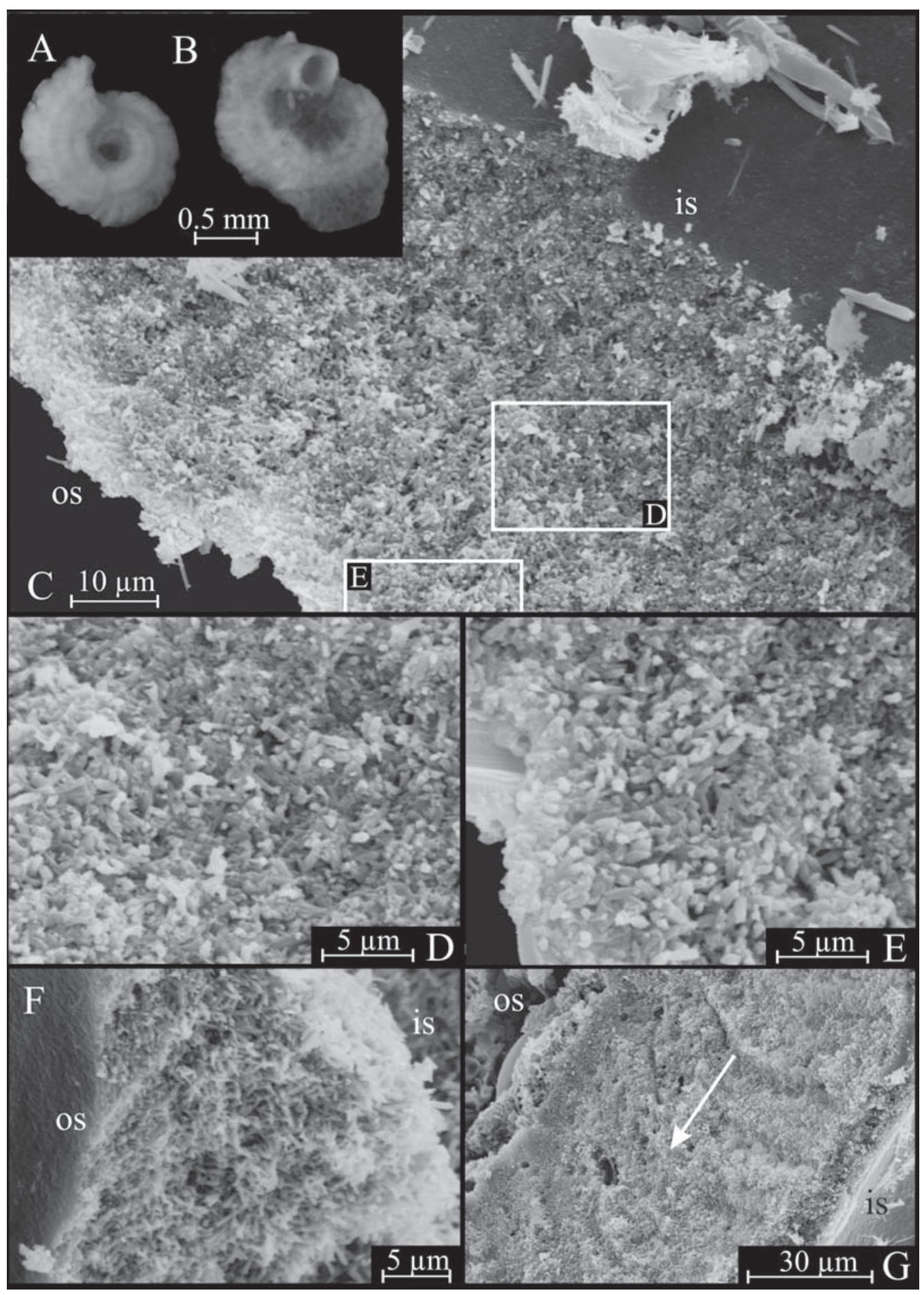




\section{Spirorbis (Spirorbis) marioni Caullery et Mesnil, 1897}

\author{
Fig. 6A-H.
}

For descriptions see Caullery, Mesnil, 1897: 199200, Pl. VII, fig. 6; Knight-Jones P. et al., 1979: 426, Fig. $2 \mathrm{C}(\mathrm{a}-\mathrm{d})$.

Material examined. Two specimens were studied with SEM in longitudinal sections (IPEE No. 2/2571, aquarium of the Plymouth Marine Laboratory, UK, depth $0.3 \mathrm{~m}$, on stones, origin is unknown). Mineralogy was analyzed using a set of tubes fragments from the same sample. External tube morphology is illustrated using specimens from the same sample as was used for SEM and IPEE No. 1/2567 (Lost Canteno, Grand Canary, Canary Islands, 5-15 m, on stones). Specimens used for examination were all dextral.

Tube morphology. Tubes are typically dextral (Fig. 6A-C), but a sinistral population is known from St. Helena Island only. Tubes are planospiral or with overlapping whorls; last whorl is often turned upwards from the substrate (Fig. 6C), coil diameter is about $1 \mathrm{~mm}$. Tube surface is white opaque with non-porcellaneous surface. Tube is usually sculptured with two low longitudinal keels, one towards the periphery, another on the inner side of the whorl, making the tube somewhat quadrangular in cross section (Fig. 6A-C). Peripheral attachment flange may be present (Fig. 6B).

Tube ultrastructures. Though wall is unilayered, having IOP structure (Fig. 6D), inner half of the wall is distinctly different from the outer half as in the former crystals are elongated up to $4 \mu \mathrm{m}$ long with corresponding width of $1 \mu \mathrm{m}$, with blunt and somewhat irregular apexes (Fig. $6 \mathrm{D}-\mathrm{F})$, and cement is almost absent. Innermost wall zone underlying the organic lining has somewhat smaller crystals $(2-3 \mu \mathrm{m}$ long, $0.5-$ $0.75 \mu \mathrm{m}$ wide) cemented together (Fig. 6E).
Outer half of the wall consists of smaller crystals (up to 2.5-3 $\mu \mathrm{m}$ long) of the same elongated appearance, but densely cemented so that individual crystals cannot be easily distinguished (Fig. 6D, G). Internal wall generally has the same ultrastructure as the external one (Fig. $6 \mathrm{H}$ ), but outer cemented zone of the wall is relatively thicker. In the early coils the crystals are isometric, much smaller (less than $1 \mathrm{im}$ in diameter) and very densely cemented (Fig. 6H). No details of inner organic lining were observed.

Tube mineralogy. 90\% aragonite $\left(\mathrm{I}_{\mathrm{arag}}=73\right)$, $10 \%$ calcite $\left(\mathrm{I}_{\text {calc }}=7\right)$.

Distribution. At the Pacific coast of the North America the species is known from $\mathrm{La}$ Paz (Mexico) to Panama (Knight-Jones et a al., 1979). It is also known in the Pacific from Galapagos Islands (Bailey, Harris, 1968), Hawaii (Vine et al., 1972), and Easter Island (Kohn, Lloyd, 1973), Japan (Uchida, 1978), and Australia (Knight-Jones P., Knight-Jones E.W., 1984). In the subtropical waters of the Atlantic the species is recorded from Grand Canary and St. Helena Islands (Knight-Jones P. et al., 1979). It is abundant in the Mediterranean (KnightJones E.W., Knight-Jones P., 1980; Bianchi, 1981; Zibrowius, Bianchi, 1981). Most likely $S$. (S.) marioni originated from Eastern Pacific and later was distributed to other areas by ships (e.g. Knight-Jones E.W., Knight-Jones P., 1980; Bianchi, 1981; Zibrowius, Bianchi, 1981; Knight-Jones P. et al., 1991).

Ecology. Found intertidally on rocks and stones.

Remarks. Porcellaneous and semitransparent tubes may gradually degrade into non-porcellaneous and opaque (Rzhavsky, pers. obs.)

Fig. 5. Spirorbis (Spirorbis) inornatus. A - planospiral tube with peripheral flange; B-G - tube ultrastructures, specimen 1: B - general view of the longitudinal section; C-E - details of the wall parts with relatively large amount of cement; F — attachment surface seen from the side of (removed) substrate; $\mathrm{G}$ - general view of the lumen showing numerous indentations on the inner organic lining; $\mathrm{H}$ - specimen 2 , details of IOP ultrastructure of the main layer.

Abbreviations: os - outer surface, is - inner surface. Large arrows indicate the direction of tube growth.

Рис. 5. Spirorbis (Spirorbis) inornatus. А - планоспиральная трубка с периферийным флангом; В-G ультраструктуры трубок, экземпляр № 1: В - общий вид стенки в продольном сечении; C-E различные участки стенки со значительным количеством цемента; F — поверхность прикрепления трубки, вид со стороны субстрата (сам субстрат удален); G - общий вид полости трубки с многочисленными темными вдавленностями на внутренней органической мембране; $\mathrm{H}$ - экземпляр № 2, структура хаотически ориентированных призматических кристаллов основного слоя.

Условные обозначения: os - наружная поверхность, is - внутренняя поверхность. Большие стрелки указывают направление роста трубки. 


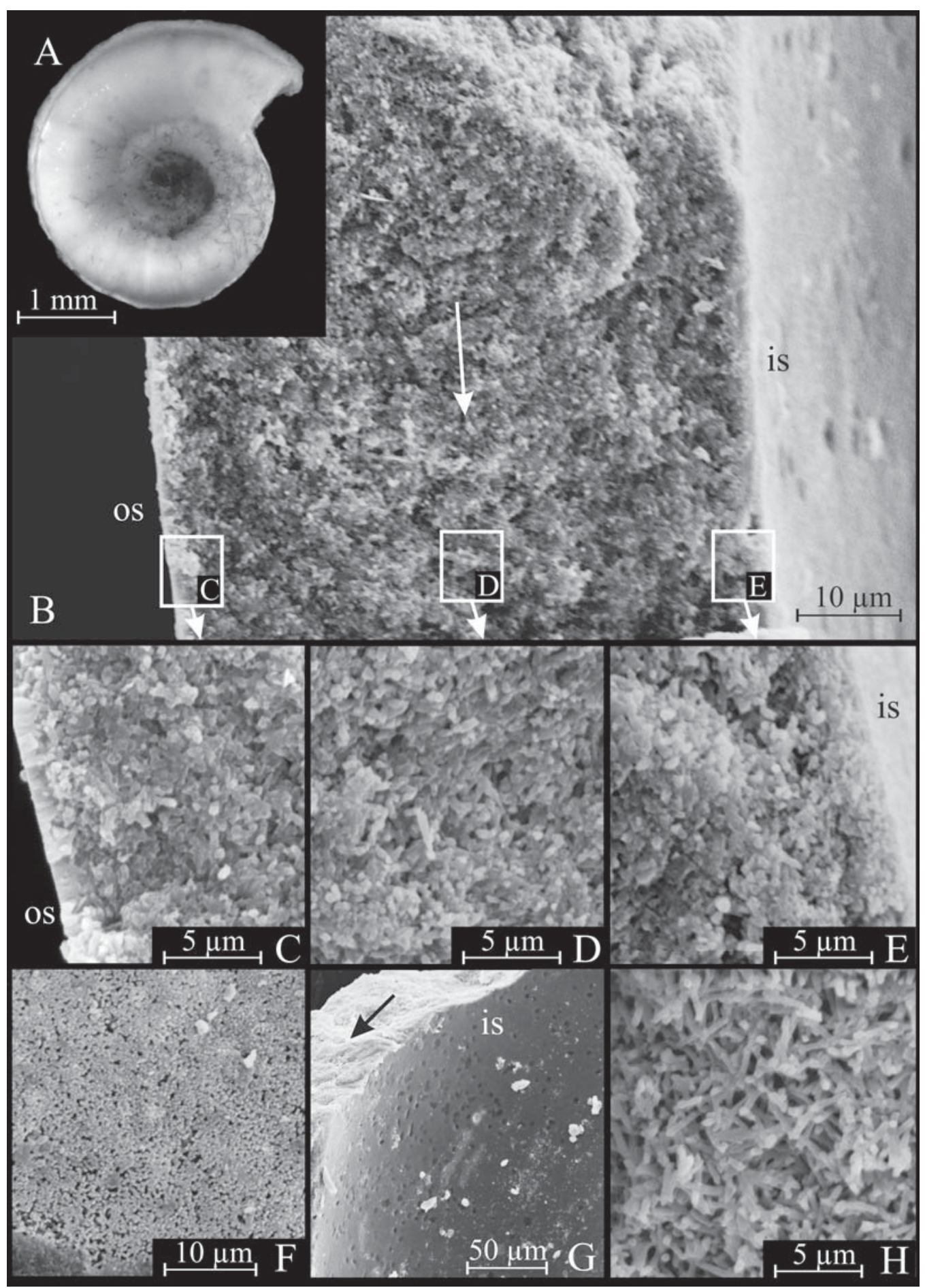


when kept for a long time in a preserving liquid. Non-porcellaneous appearance of the tube surface in $S$. (S.) marioni observed in our material might be such a preservation artifact as data on this feature are absent in literature. However, all Spirorbini with unilayered IOP are characterized by non-porcellaneous tube surface (see Discussion below), thus indicating that this character state is probably original for $S$. ( $S$.) marioni too.

Inner organic lining bears numerous indentations (Fig. 6H) similar to those found in $S$. (S.) corallinae and $S$. (S.) inornatus, showing their highest concentration on the external side of the tube coil.

\section{Spirorbis (Spirorbis) rothlisbergi Knight- Jones, 1978}

Fig. 7A-G.

For descriptions see Knight-Jones P., 1978: 205-206, Fig. 2A-J; Knight-Jones P. et al., 1979: 426, Fig. 2D (a-e).

Material examined. One specimen was studied with SEM in longitudinal section (IPEE No. 1/2512, La Jolla, California, USA on brown algae Egregia sp., from ashore casts; from the type series). Mineralogy was analyzed using a single tube and external tube morphology is illustrated using specimens from the same sample.

Tube morphology. Tubes are dextral, planospiral, up to $2 \mathrm{~mm}$ in coil diameter, round in cross-section, without longitudinal sculpture (Fig. 7A, B). Tube surface is smooth, white opaque, somewhat porcellaneous. Peripheral attachment flange may be present.

Tube ultrastructures. The wall is threelayered (Fig. 7C), inner and outer layers have spherulitic prismatic (SPHP) structure, and the main middle layer has IOP structure. Outer SPHP layer (Fig. 7F) has width of $\sim 10 \mu \mathrm{m}$ (corresponding wall width is $80 \mu \mathrm{m}$ ), and some- what irregular appearance as spherulites may have irregular shapes, and are often inclined to variable angles towards outer surface. The boundary between SPHP layer with underlying IOP layer is not rectilinear. Middle IOP layer (Fig. 7E) consists of elongated rice grain-like crystals (length of $2.5-3 \mu \mathrm{m}$, width of $0.5-0.75$ $\mu \mathrm{m}$; some are smaller and more isometric) with irregular blunt apexes. Sometimes the shape of crystals is slightly curved. Cement content in the middle layer is low. The crystal appearance does not change throughout the layer, except for marginal zones immediately underlying inner and outer SPHP layers: elongated crystals here become less frequent than isometric ones. Inner layer with SPHP structure (Fig. 7D) is thicker in the last whorl than outer SPHP layer $(\sim 18-20 \mu \mathrm{m})$, but in the foregoing whorl both SPHP layers have the same thickness $(\sim 4-5 \mu \mathrm{m}$; corresponding wall width is $12-13$ $\mu \mathrm{m}$; Fig. 7G). Spherulites of the inner SPHP layer are very regular, oriented subperpendicular towards the lumen, and densely consolidated. In one section of internal wall the outer SPHP layer was not observed. No clear growth lamellae and details of inner organic lining were observed.

Tube mineralogy. $100 \%$ calcite $\left(\mathrm{I}_{\text {calc }}=51\right)$.

Distribution. The species is known only from the Pacific coast of USA (La Jolla, California) (Knight-Jones P. et al., 1979).

Ecology. On the brown algae Egregia sp. from ashore casts.

Remarks. Data on $S$. (S.) rothlisbergi tube structure (Ippolitov, Rzhavsky 2008: Fig. 1a) are extended here with additional figures and detailed description as well as data on mineralogy and external morphology of the tube.

Fig. 6. Spirorbis (Spirorbis) marioni. A-C - tubes: A - IPEE No. 2/2571; B, C - IPEE No. 1/2567; D$\mathrm{H}$ - tube ultrastructures: $\mathrm{D}$ - general view of the longitudinal section; $\mathrm{E}-\mathrm{G}$ - details of the wall parts with large amount of cement in the outer half of the wall; $\mathrm{H}$ - longitudinal section through area of coils contact in early growth stages showing extremely thin wall on the internal side of the whorl and indentations on the inner organic lining.

Abbreviations: os - outer surface, is - inner surface, wi - tube wall on the internal side of the last coil, we - tube wall on the external side of the next to last coil. Large arrows indicate the direction of tube growth.

Рис. 6. Spirorbis (Spirorbis) marioni. A-C - трубки: А - IPEE No. 2/2571; B, C - IPEE No. 1/2567; D$\mathrm{H}$ - ультраструктуры трубок: D - общий вид стенки в продольном сечении; $\mathrm{E}-\mathrm{G}$ - различные участки стенки с более высоким содержанием цемента во внешней половине стенки; Н - продольное сечение через смыкание оборотов на ранних стадиях роста с очень тонкой стенкой на внутренней стороне позднего оборота, также заметны вдавленности на внутренней органической мембране трубки.

Условные обозначения: os - наружная поверхность, is - внутренняя поверхность, wi - стенка внутренней стороны позднего оборота; we - стенка наружной стороны раннего оборота. Большие стрелки указывают направление роста трубки. 


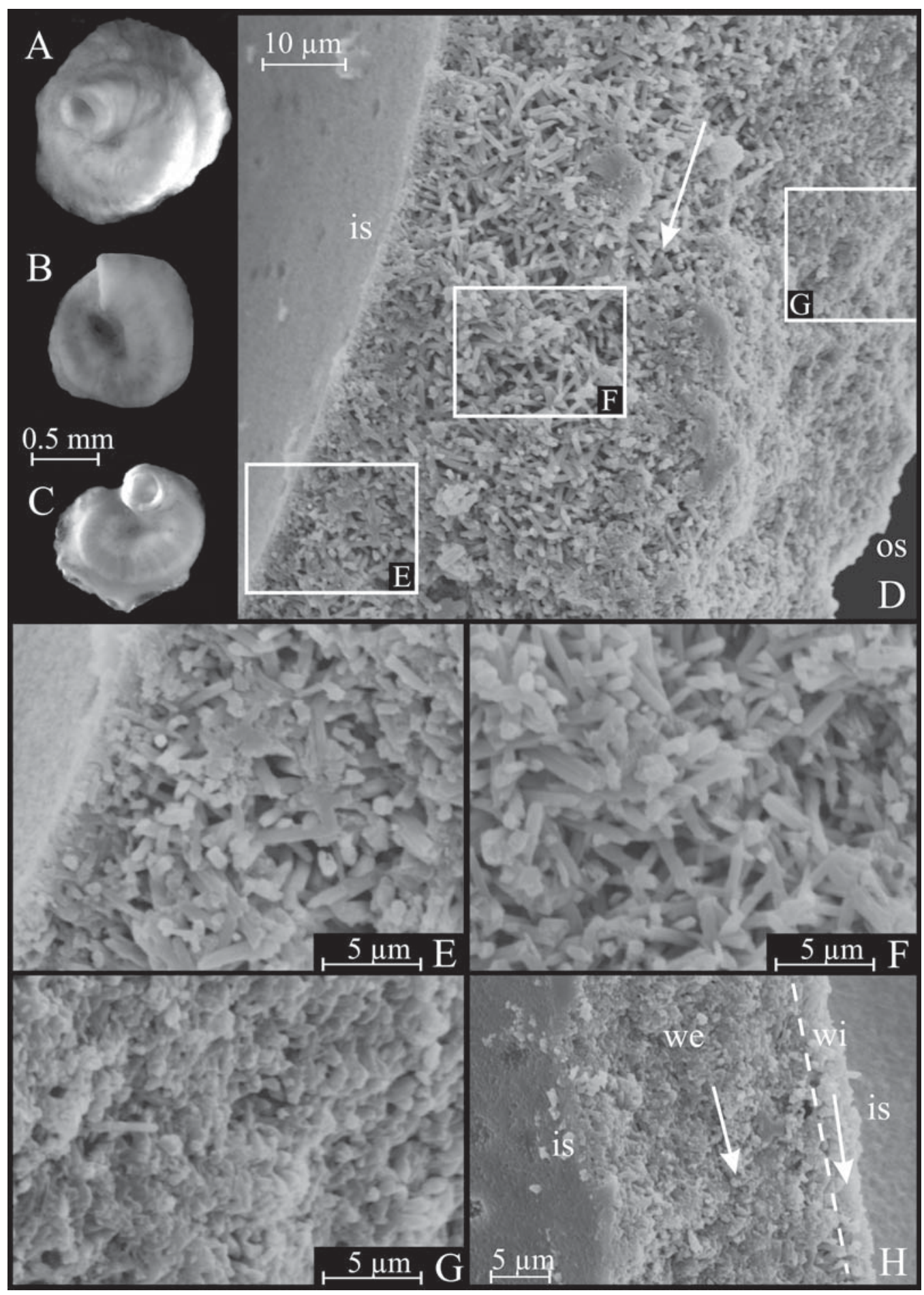




\section{Spirorbis (Spirorbis) rupestris Gee et Knight-Jones, 1962}

Fig. 8A-I.

For descriptions see Gee, Knight-Jones E.W., 1962: 642-643, fig. 1A-G; Knight-Jones E.W., 1977: 460-461, fig. 2K-P; Rzhavsky et al., 2014: 139-142, Fig. 35A-F, P1. 2E, F.

Material examined. One specimen was studied with SEM in longitudinal section (IPEE No. 1/2548, West Angel Bay, Bristol Bay, UK, middle littoral, on stones). Mineralogy was analyzed using a single tube and a set of several tubes, both from the same sample. External tube morphology is illustrated using specimens from the IPEE No. 3/2883 (Telegraph Bay, Tromsø, Norway, low littoral, on stones).

Tube morphology. Tubes are sinistral, unsculptured, usually planospiral (Fig. 8A), although last whorls may be overlapping (Fig. 8B) or straightened (evolute) (Fig. 8C). Coil diameter of the planospiral tube part is up to 4.5 $\mathrm{mm}$. Peripheral flange is always absent. Tubes are often covered with the calcareous red algae Phymatolithon purpureum (P.L. Crouan et H.M. Crouan) Woelkerling et L.M. Irvine, 1968 ( $=P$. polymorphum in older literature) sometimes leaving only the mouth visible (Fig. 8C). Tube surface is white opaque, somewhat porcellaneous when not covered by algae.

Tube ultrastructures. The tube wall is twolayered, consisting of a thicker main layer and a thinner outer one (Fig. 8D). The main layer has IOP structure and the outer layer has SPHP structure. The main layer consists of small elongated crystals with length up to $1.5 \mu \mathrm{m}$ and corresponding width up to $0.5 \mu \mathrm{m}$ (Fig. 8D, F) of somewhat irregular shape and slightly pointed ends. The crystals are consolidated by abundant cement in some areas, while in others they are more or less loose, especially in the outer half of the wall. Outer SPHP layer (Fig. 8E) is 6-10 $\mu \mathrm{m}$ wide in the last coil (corresponding wall thickness is $\sim 80 \mu \mathrm{m}$ ) and has irregular non-rectilinear boundary with main IOP layer. Internal wall observed at the last whorl (Fig. $8 \mathrm{H})$ is very thin $(15-20 \mu \mathrm{m}$, while corresponding external wall is $70-80 \mu \mathrm{m}$ thick) and lacks outer consolidated SPHP layer. Walls of early growth stages are composed of mostly isometric crystals embedded in amorphous cement. The axis of poorly defined parabolic growth lamellae is slightly displaced towards the outer side of the wall. Inner organic lining is $1-2 \mu \mathrm{m}$ thick.

Tube mineralogy. $100 \%$ calcite $\left(\mathrm{I}_{\text {calc }}=583\right.$ and 73). Analysis of the set of tubes has shown high $\mathrm{Mg}$ content in calcite, while analysis of the single tube has shown low Mg content.

Distribution. The species is well known in the North Atlantic off the British and Irish shores and Brittany, France (Knight-Jones P., Knight-Jones E.W., 1977). In the Arctic it is recorded from the Norwegian Sea off Tromsø (Rzhavsky et al., 2014) and off Norway coast without an indication of the exact locality (Knight-Jones P. et al., 1991).

Ecology. S. (S.) rupestris prefers fairly well illuminated stones and rocks in the lower intertidal zone, particularly with low siltation rate. The species is susceptible to sand abrasion, but

Fig. 7. Spirorbis (Spirorbis) rothlisbergi. A-B - tubes; $\mathrm{C}-\mathrm{G}$ - tube ultrastructures: $\mathrm{C}$ - general view of the longitudinal section; D - details of the inner SPHP layer, note its thickness and regular appearance of spherulites; E - middle part of the wall with IOP structure; F — details of the outer SPHP layer with irregular spherulite shape and orientation; $\mathrm{G}$ - longitudinal section through the area of coils contact in early growth stages with irregular appearance of the outer SPHP layer in the early coil and isometric crystal shapes in the middle IOP layer.

Abbreviations: os - outer surface, is - inner surface, wi — tube wall on the internal side of the last coil, we - tube wall on the external side of the next to last coil. Large arrow indicates the direction of tube growth.

Рис. 7. Spirorbis (Spirorbis) rothlisbergi. А-B - трубки; C-G - ультраструктуры трубок: C- общий вид стенки в продольном сечении; D - внутренний слой со сферулитовой призматической структурой, хорошо заметна его значительная толщина и правильное расположение сферулитов; $\mathrm{E}-$ средняя часть стенки со структурой хаотически ориентированных призматических кристаллов; F — наружный слой со сферулитовой призматической структурой, сферулиты имеют невыдержанную ориентировку и часто неправильную форму; $\mathrm{G}$ - продольное сечение через смыкание оборотов на ранних стадиях роста, сферулиты наружного слоя имеют неправильную форму, а кристаллы среднего слоя изометичны. Условные обозначения: os - наружная поверхность, is - внутренняя поверхность, wi - стенка внутренней стороны позднего оборота; we - стенка наружной стороны раннего оборота. Большая стрелка указывает направление роста трубки. 


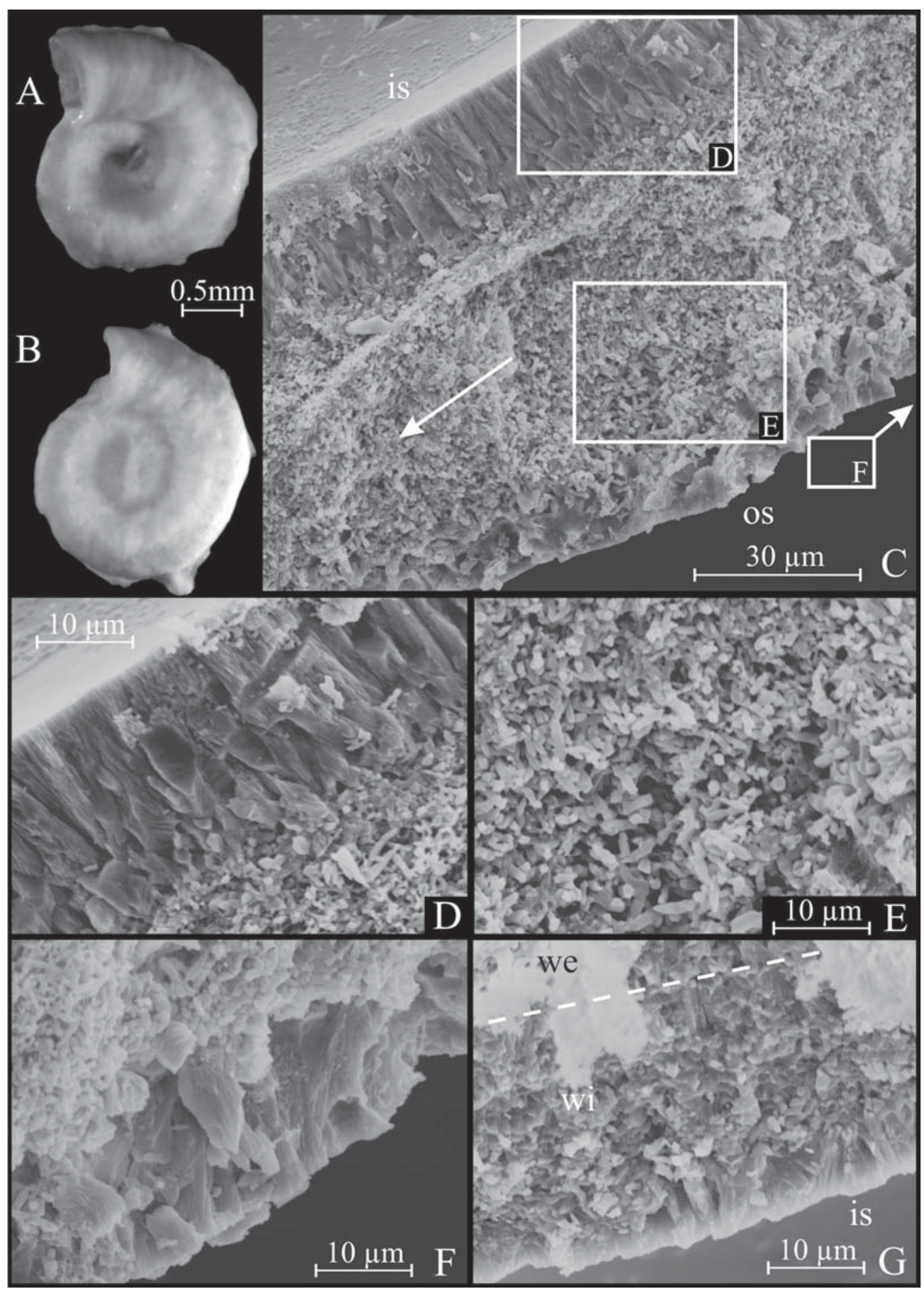


tolerant of reduced salinity. It is closely associated with calcareous algae $P$. purpureum $(=P$. polymorphum in older literature) (see KnightJones P., Knight-Jones E.W., 1977).

Remarks. The inner tube surface has numerous indentations (Fig. 8I), probably produced by chaetal anchorage.

Spirorbis cf. rupestris ultrastructurally studied by Weedon (1994) can be any other spirorbin species, as $S$. (S.) rupestris is characterized by sinistral (clockwise) tube, while Weedon (1994: 8 ) reports that his material had anticlockwise coiling. Moreover, it could have even been a non-spirorbin juvenile serpulid, some of which also have spirally coiled initial tube and may be confused with spirorbins. However, tube ultrastructures described by Weedon are essentially similar to those of a true $S$. $(S$.$) rupestris.$

\section{8)}

\section{Spirorbis (Spirorbis) spirorbis (Linnaeus,}

Fig. 9A-I.

For descriptions see Knight-Jones P., Knight-Jones E.W., 1977: 457-460, Fig. 2A-J; Rzhavsky et al., 2014: 142-146, Fig. 36A-H.

Material examined. Three specimens were studied with SEM, two in longitudinal and one in transverse section (IPEE No. 3/2513, Barcelet Bay, Bristol Bay, UK, littoral, on fuci). Mineralogy was analyzed using a single tube and a set of several tubes, in both cases coming from the same sample as the material for SEM. External tube morphology is also illustrated by specimens from the same sample.
Tube morphology. Tubes are sinistral, unsculptured, planospiral (Fig. 9A, B), usually with peripheral flange increasing area of attachment to substrate; coil diameter is up to 3 (rarely 4) $\mathrm{mm}$. Surface is white opaque, slightly porcellaneous.

Tube ultrastructures. The tube wall is twolayered, consisting of a thicker main layer and a thinner outer one (Fig. 9C). The main layer of the tube is represented by irregularly oriented elongated rice grain-like crystals up to $1.5-2 \mu \mathrm{m}$ long and $0.5-0.75 \mu \mathrm{m}$ wide, forming IOP structure (Fig. 9E, I). Locally crystals may be more elongated and slender up to $0.25-0.3 \mu \mathrm{m}$ wide. Crystal size is more or less uniform throughout the layer. In one transverse section crystal sizes were found to be approximately twice as large as normally. Such enlarged crystals are common around areas of the coil contacts in the upper and lower part of the cross-section and near the attachment flanges, where the wall attains its maximum thickness. The outer part of the IOP layer is characterized by a relatively high content of amorphous matter, making distinguishing of individual crystals difficult (Fig. 9D, E, G). The lowest cement content is observed in the middle part of the wall.

Outer, relatively thin layer $(5-6 \mu \mathrm{m}$ wide with corresponding wall width of $60 \mu \mathrm{m}$ ) has SPHP structure (Fig. 9F) and variable width. In two of the examined specimens the width of SPHP layer ( 9 and 5-6 $\mu \mathrm{m}$ ) was $10 \%$ of the

Fig. 8. Spirorbis (Spirorbis) rupestris. A-C - tubes: A - planospiral tube with slightly evoluted last coil on red algae Phymatolithon purpureum; B — specimen with overlapping coils; C - planospiral specimen with evoluted last coil overgrown by red algae $P$. purpureum; D-I - tube ultrastructures: D — general view of the longitudinal section; E - details of the outer SPHP layer; F - details of the middle part of the wall; $\mathrm{G}$ - details of the innermost part of the wall, with dense consolidation of crystals by cement near the lumen; $\mathrm{H}$ - longitudinal section through the area of coils contact; I - general view of the lumen with numerous irregularly allocated indentations.

Abbreviations: os - outer surface, is - inner surface, wi - tube wall on the internal side of the last coil, we - tube wall on the external side of the next-to-last coil. Large arrows indicate the direction of tube growth.

Рис. 8. Spirorbis (Spirorbis) rupestris. А-C - трубки: А - планоспиральная трубка со слегка распрямлённым последним оборотом, прикреплённая к красной водоросли Phymatolithon purpureum; В - экземпляр с налегающими друг на друга оборотами; C - планоспиральная трубка с распрямлённым последним оборотом и поверхностью, обросшей красной водорослью P. purpureum; D-I ультраструктуры трубок: D - общий вид стенки в продольном сечении; $\mathrm{E}$ - наружный слой со сферулитовой призматической структурой; $\mathrm{F}$ - средняя часть стенки; $\mathrm{G}$ - внутренняя часть стенки с выраженной консолидацией цементом близ внутренней полости; $\mathrm{H}$ - продольное сечение через смыкание оборотов; I - общий вид внутренней полости с многочисленными нерегулярно расположенными вдавленностями на органической мембране.

Условные обозначения: os - наружная поверхность, is - внутренняя поверхность, wi - стенка внутренней стороны позднего оборота; we - стенка наружной стороны раннего оборота. Большие стрелки указывают направление роста трубки. 


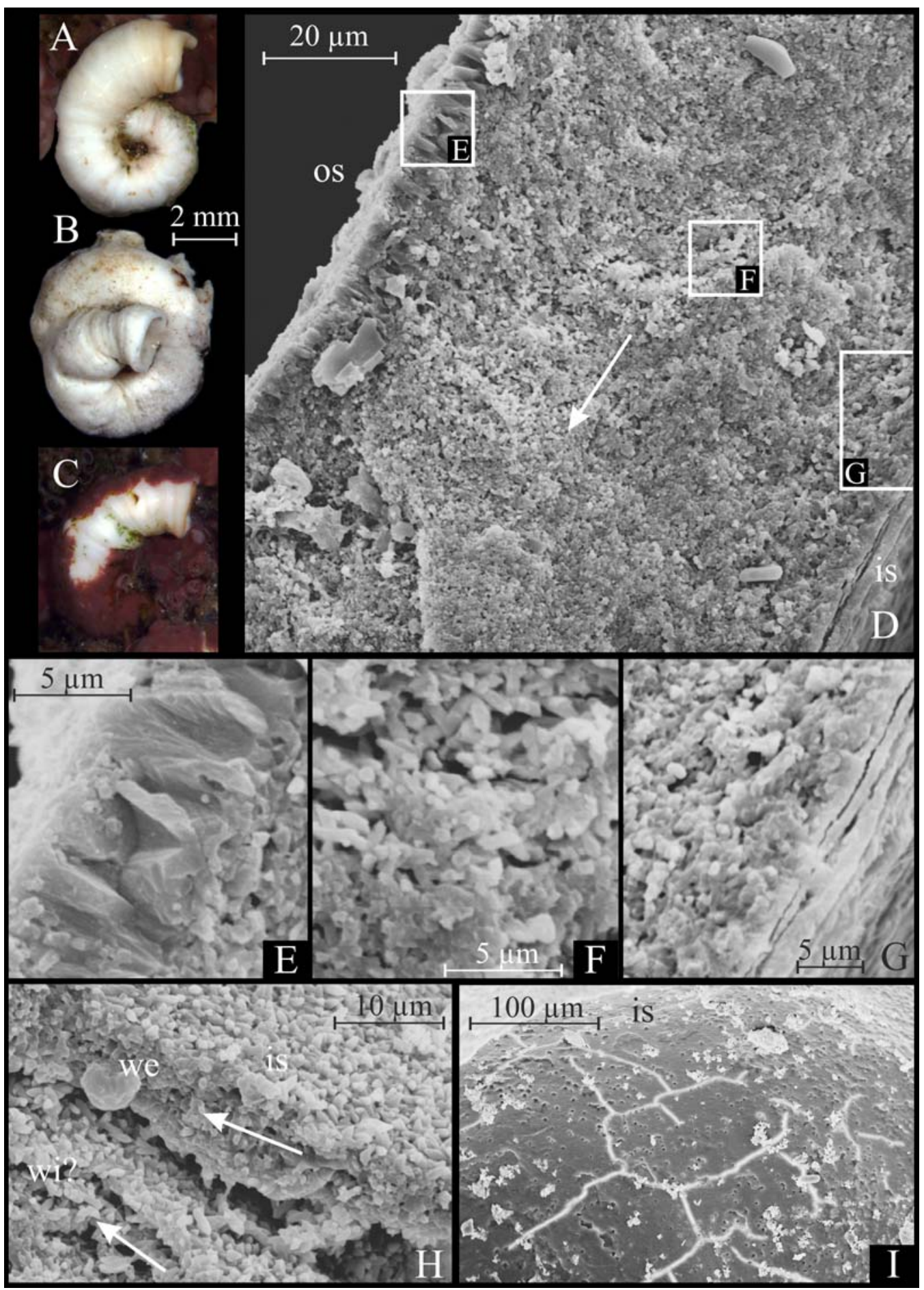


corresponding wall width ( $\sim 90$ and $60 \mu \mathrm{m}$ respectively). In another specimen the observed width of SPHP layer was $8 \mu \mathrm{m}$, making up $27 \%$ of the corresponding wall width $(30 \mu \mathrm{m})$, while in the early growth stages SPHP layer was $2 \mu \mathrm{m}$ thick, which is $31 \%$ of the corresponding wall width $(6.5 \mu \mathrm{m})$. The boundary between IOP and SPHP layer is irregular.

Internal wall has structure is different from the type described above. In one examined specimen, the outer SPHP layer was completely absent for all growth stages. In another, internal wall of the early growth stages did not show SPHP outer layer either, but the internal side of the last coil had unilayered SPHP wall (Fig. 9G).

Parabolic growth lamellae are often wellvisible on longitudinal sections, have steep slopes and the axis located in the center of the wall (Fig. 9C). The thickness of the inner organic lining observed both in early growth stages and in the last coil does not exceed $0.5 \mu \mathrm{m}$.

Tube mineralogy. $100 \%$ calcite $\left(\mathrm{I}_{\text {calc }}=33\right.$ and 218), doubtful aragonite was found in a sample prepared from a single specimen (see Remarks).

Distribution. In the North Atlantic the species is distributed around Britain, Ireland, West Sweden, and Brittany, France (Knight-Jones P., Knight-Jones E.W., 1977). The report of this species from Nova Scotia, Canada (Doyle, 1974;
Knight-Jones P., Knight-Jones E.W., 1977) needs to be verified. In the Arctic $S$. (S.) spirorbis is recorded from the White and Barents Seas (Rzhavsky, 1992, 2001), Iceland (Knight-Jones P. et al., 1991) and Norwegian Sea (Bergan, 1953). Although $S$. (S.) spirorbis is suggested to be a common species building abundant aggregations on fuci in the Atlantic sector of the Arctic Ocean, in the existing museum collections such materials are scarce. In view of our new data (Rzhavsky et al., 2014) there is a need to re-examine the habitats and geographical distribution of $S$. (S.) spirorbis in the Arctic.

Ecology. The species is found almost exclusively intertidally on fuci. Sometimes $S$. (S.) spirorbis is attached to algae such as Laminaria, Ascophyllum, and Sacchorhiza; exceptionally it is found on stones under button-shaped thalli of the Himanthalia.

Remarks. On early coils of one specimen we observed relief of concentric structures (spirals?) embedded into (or buried under) inner organic lining of the tube (Fig. 9I). These structures cover the whole area of lumen, count up to 16 whorls and often overlap. Neighboring coils of spirals may be in contact or disconnected. We propose that these structures may be interpreted as specific substructure of the inner organic lining that locally also bears round imprints, probably reflecting traces of touches by worm's chaetae.

Fig. 9. Spirorbis (Spirorbis) spirorbis. A, B - planospiral tubes with peripheral flange; $\mathrm{C}-\mathrm{G}-$ tube ultrastructures, specimen 1: $\mathrm{C}$ - general view of the longitudinal section; $\mathrm{D}$ - details of the innermost part of the wall; E - details of the middle part of the wall; F - outer SPHP layer; G - crystals of the middle part of the wall, not embedded into cement; $\mathrm{H}, \mathrm{I}$ - tube ultrastructures, specimen 2: $\mathrm{H}$ - longitudinal section through the area of early coils contacts, internal wall of the later coil is unilayered with SPHP structure; I - general view of the lumen with strange concentric structures embedded under the inner organic lining; long object is a diatom.

Abbreviations: os - outer surface, is - inner surface, wi - tube wall on the internal side of the last coil, we - tube wall on the external side of the next to last coil. Large arrows indicate the direction of tube growth.

Рис. 9. Spirorbis (Spirorbis) spirorbis. А,В - планоспиральные трубки с выраженным периферийным флангом; $\mathrm{C}-\mathrm{G}$ - ультраструктуры трубок, экземпляр № 1: C - общий вид стенки в продольном сечении; D - внутренняя часть стенки; Е - средняя часть стенки; F - наружный слой со сферулитовой призматической структурой; $\mathrm{G}$ - призматические кристаллы в средней части стенки, не скрепленные цементом; Н, I - ультраструктуры трубок, экземпляр № 2: Н — продольное сечение через смыкание оборотов на ранних стадиях роста, стенка трубки на внутренней стороне оборота однослойная и имеет сферулитовую призматическую структуру; I - общий вид внутренней полости трубки с концентрическими структурами неясной природы, расположенными под органической мембраной; удлиненный объект - створка диатомеи.

Условные обозначения: os - наружная поверхность, is - внутренняя поверхность, wi - стенка внутренней стороны позднего оборота; we - стенка наружной стороны раннего оборота. Большие стрелки указывают направление роста трубки. 


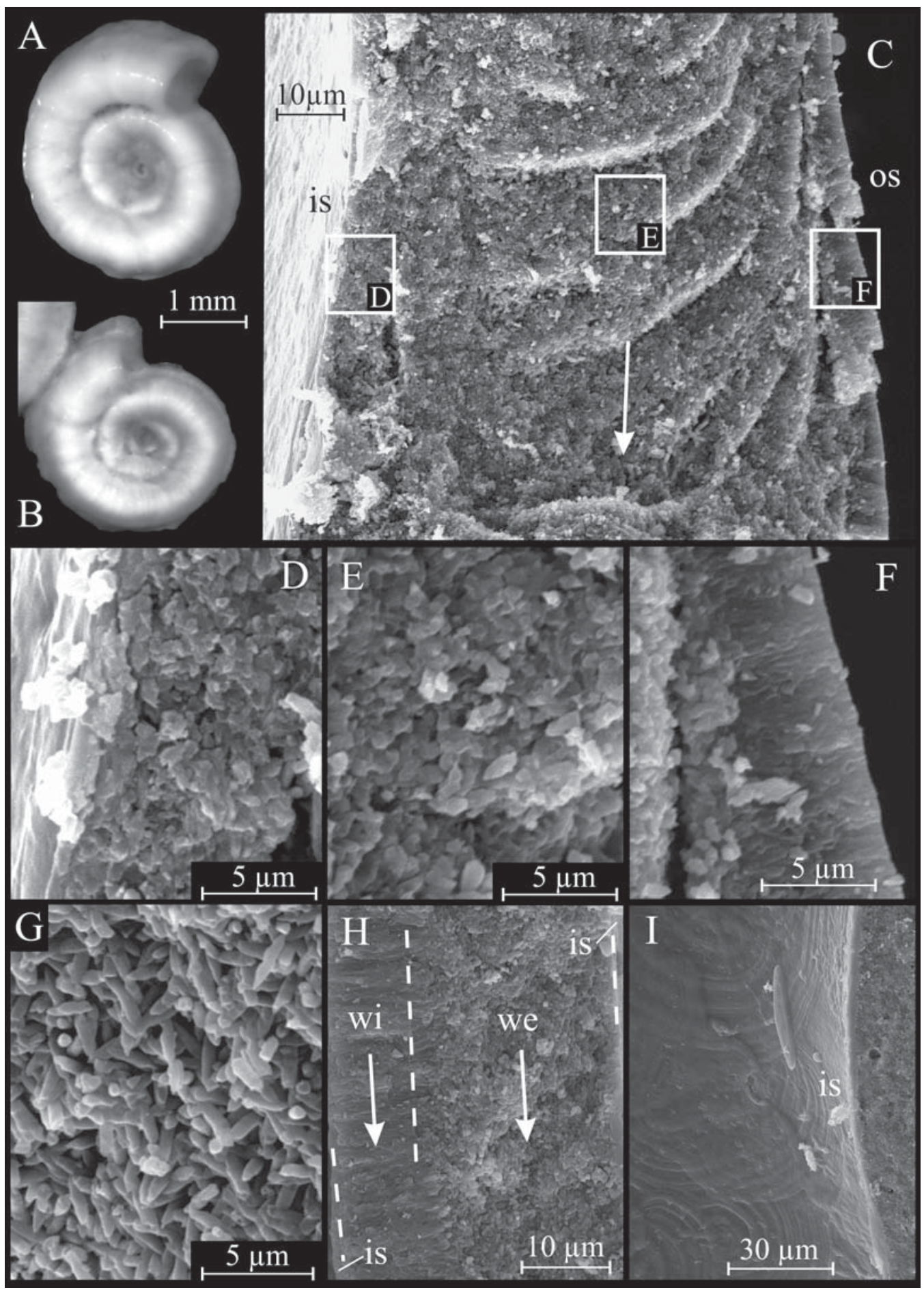


Mineralogical analysis suggested traces of aragonite in a sample made of a single tube $\left(\mathrm{I}_{\text {arag? }}=6\right.$ corresponding to aragonite content up to $10-15 \%$ ), but the main peak is somewhat shifted relative to normal position (spacing between diffracting planes $\mathrm{d}=3.45 \mathrm{~A}$ ). Low reliability of analysis prevents us from making conclusion about presence of aragonite. Because another sample, made from the set of specimens and providing more reliable results, has clearly shown the absence of aragonite, we consider that $S$. (S.) spirorbis has purely calcitic tubes. Similarly, $10.5 \%$ aragonite content was recorded from a specimen of $S$. (S.) spirorbis (as "borealis") by Bornhold and Milliman (1973), but specific and even generic affiliation of their material is doubtful.

The tube structure of $S$. (S.) spirorbis described here is fully concordant with those reported by Sanfilippo (1998: Pl. 2, Fig. 3-5) for recent specimens from Iceland. However, her fossil tubes described under the same name from the Early Pleistocene of Italy (Sanfilippo, 1998, Pl. 2, Fig. 6, 7) do not show an outer SPHP layer. The author interpreted such a difference as a result of post-mortem alteration of carbonate material. However, as structure of Pleistocene "Spirorbis spirorbis" resembles that of $S$. (S.) inornatus, the difference may alternatively be explained by misidentification of empty tubes. Fossil specimens described as "Spirorbis spirorbis" may also belong to the tribe Pileolariini Knight-Jones, 1978, some species of which are known from the Mediterranean and have unsculptured tubes morphologically similar to those of $S$. (S.) spirorbis. Pileolariini tube structures also look similar to those described by Sanfilippo for fossil "Spirorbis spirorbis" (Ippolitov, Rzhavsky, unpubl.).

\section{Spirorbis (Spirorbis) strigatus Knight- Jones, 1978}

Fig. $10 \mathrm{~A}-\mathrm{C}$.

For descriptions see Knight-Jones P., 1978: 208-209, Fig. 4A-J.

Material examined. Two specimens were studied with SEM in longitudinal sections (IPEE No. 1/2549, Fuerteventura Island, Canary Islands, Spain, depth $0.5 \mathrm{~m}$, on stones; from the type series). Mineralogy was analyzed using a set of three tubes plus some fragments from the same sample. External tube morphology is illustrated using specimens from the same sample.
Tube morphology. Tubes are sinistral, planospiral, coil diameter up to $1.5 \mathrm{~mm}$. Tube surface is white opaque, non-porcellaneous. There are usually two distinct longitudinal keels on the upper side, one running towards the periphery of the whorl, another on the inner edge, making a tube somewhat quadrangular in cross section, although some specimens may have three distinct longitudinal keels (Fig. 10A), the median one being the most pronounced.

Tube ultrastructure. The tube wall is unilayered, with IOP structure (Fig. 10B, C). Crystals are elongated with blunt ends, up to $2.5-3 \mu \mathrm{m}$ long and up to $0.5-0.75 \mu \mathrm{m}$ wide in the inner half of the wall. Within the thin innermost zone, as well as in the outer half, the size of crystals is smaller (length up to $1-1.5 \mu \mathrm{m}$, width about $0.25 \mu \mathrm{m})$. All transitions between zones with different appearance of crystals are subtle. Cement is absent in the inner half of the wall, but is abundant in the outer half. Certain sections of the entire wall also show abundant cement. No clear growth lamellae and details of inner organic lining were observed.

Tube mineralogy. $20 \%$ calcite $\left(\mathrm{I}_{\text {calc }}=2\right), 80 \%$ aragonite $\left(\mathrm{I}_{\text {arag }}=9\right)$; low data reliability.

Distribution. Subtropical waters of the North-East Atlantic: Canary Islands (KnightJones P., 1978) and Madeira (Knight-Jones P., Knight-Jones E.W., 1995).

Ecology. The species lives intertidally and in the upper subtidal zone, on stones.

Remarks. Similar to the situation with $S$. (S.) marioni, it is unclear whether observed nonporcellaneous appearance of the tube surface in $S$. (S.) strigatus is an artifact. However, as all Spirorbini with unilayered IOP tube walls are characterized by non-porcellaneous tube surface (see Discussion), this character is probably original for $S$. (S.) strigatus.

\section{3 \\ Spirorbis (Spirorbis) tridentatus Levinsen,} Fig. 11A-I.

For descriptions see Knight-Jones P., Knight-Jones E.W., 1977: 464-466, fig. 4A-K; Rzhavsky et al., 2014: 146-149, Fig. 37A-G, P1. 2B.

Material examined. Three specimens were studied with SEM in longitudinal sections (one from IPEE No. 5/ 2564, Mumbel Point, Welsh, UK, tidal pool, on stones, and two from IPEE No. 3/2543, Abercastle Welsh, UK, low littoral, on stones). Mineralogy was analyzed using a single tube from IPEE No. 5/2564 and a set of three tubes 


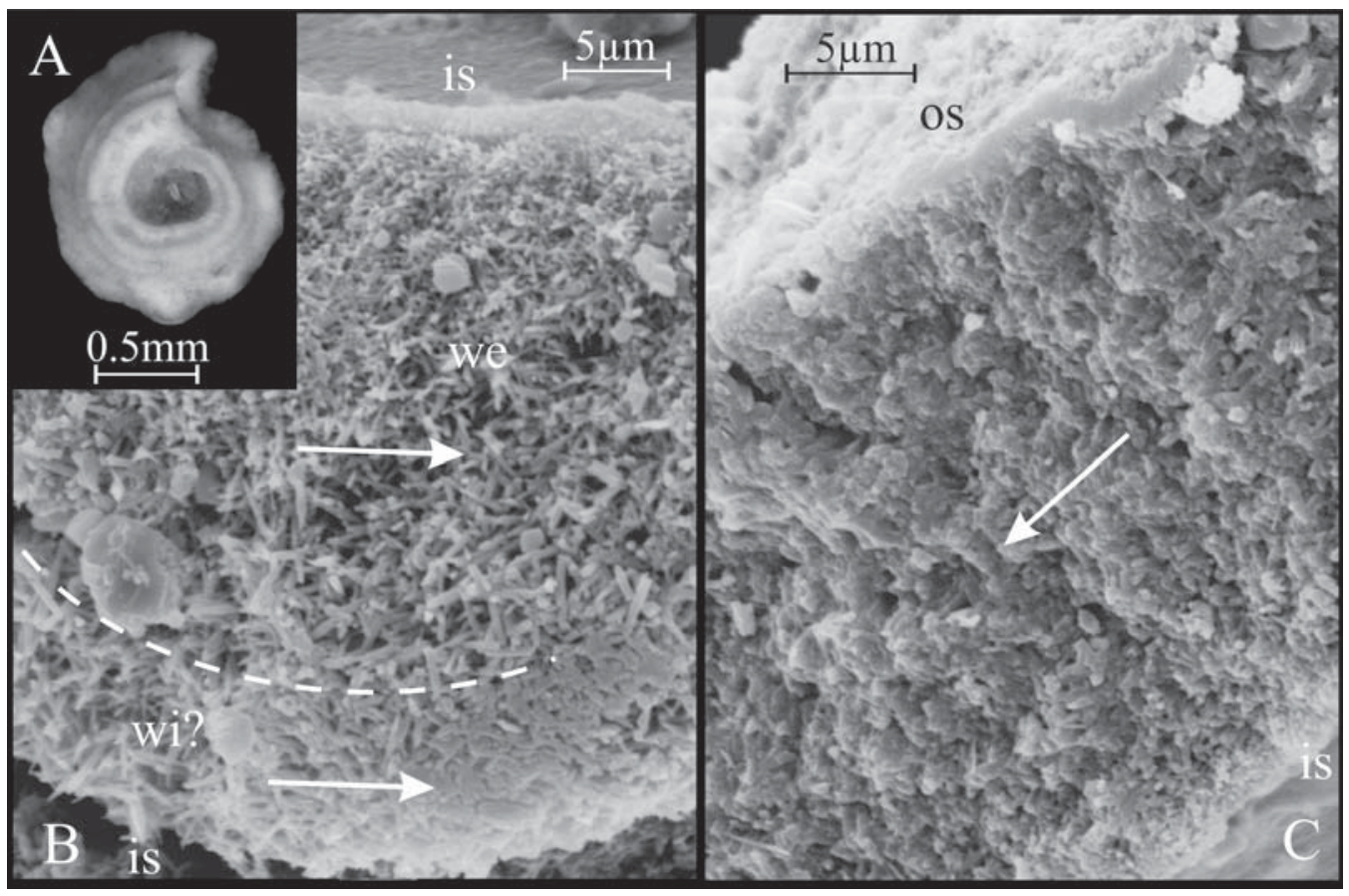

Fig. 10. Spirorbis (Spirorbis) strigatus. A - planospiral tube with three keels; B, C - tube ultrastructures; longitudinal sections in different parts of the same tube with varying amount of cement: B - through the area of coils contact; $\mathrm{C}$ - through the external wall of the last coil.

Abbreviations: os - outer surface, is - inner surface, wi - tube wall on the internal side of the last coil, we - tube wall on the external side of the next to last coil. Large arrows indicate the direction of tube growth.

Рис. 10. Spirorbis (Spirorbis) strigatus. А - планоспиральная трубка с тремя килями; В, С ультраструктуры, продольные сечения различных участков трубки, количество цемента в разных сечениях варьирует: В - сечение через смыкание оборотов; C - сечение стенки на наружной стороне последнего оборота.

Условные обозначения: os - наружная поверхность, is - внутренняя поверхность, wi - стенка внутренней стороны позднего оборота; we - стенка наружной стороны раннего оборота. Большие стрелки указывают направление роста трубки.

plus fragments from IPEE No. 3/2543. External tube morphology is illustrated using specimens from IPEE No. 6/2876, Telegraph Bay, Barents Sea, Tromsø, Norway, low littoral, on stones.

Tube morphology. Tubes are sinistral, planospiral, thick-walled with coil diameter up to $3.5 \mathrm{~mm}$; surface is white opaque, porcellaneous. Adult tubes have three distinct massive keels (Fig. 11A, B) ending as projections over the aperture; juvenile tubes are unsculptured (Fig. 11C). Last whorl tends to cover previous ones and to widen rapidly towards the mouth.

Tube ultrastructures. The tube wall consists of two layers (Fig. 11D), the thick main one having irregularly oriented prismatic (IOP) structure and the thin outer layer with spherulitic prismatic (SPHP) structure. The main layer consists of fine elongated crystals up to $2-2.5 \mu \mathrm{m}$ long and $0.5-0.75 \mu \mathrm{m}$ wide, with angular blunt ends (Fig. 11F). Cement is very abundant throughout the wall, so that crystals look more or less isometric and angular (Fig. 11I) and true crystal shapes can be seen only from isolated areas. The outer SPHP layer (Fig. 11F) is very thin $(2-4 \mu \mathrm{m}$ with corresponding wall thickness of $80 \mu \mathrm{m})$ and locally may be absent. The internal wall observed in one section (Fig. $11 \mathrm{H}$, I) does not show the outer SPHP layer, while the main IOP layer has high cement content. Organic lining is thick, from 1 to $4 \mu \mathrm{m}$ in studied sections. 


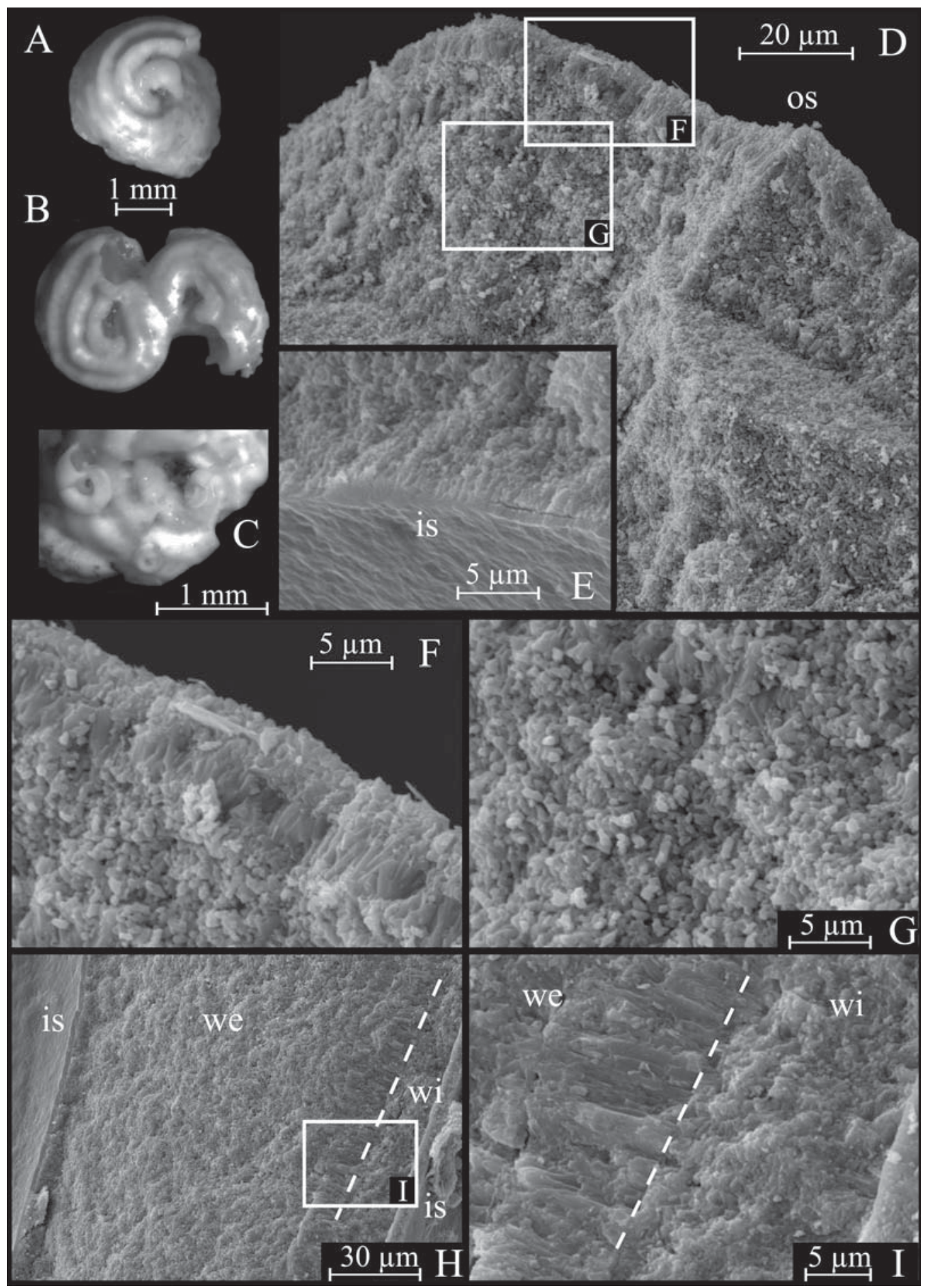


Tube mineralogy. The sample made of a set of specimens showed $100 \%$ calcite $\left(\mathrm{I}_{\text {calc }}=379\right)$ with high $\mathrm{Mg}$ content. The sample made of a single tube was predominantly calcitic $(77 \%$; $\mathrm{I}_{\text {calc }}=43$ ), while doubtful aragonite constituted $\sim 23 \%\left(\mathrm{I}_{\text {ara }}=13\right)$ with low reliability.

Distribution. The species is common in the north-eastern Atlantic. It has been reported from the coasts of Norway (Bergan, 1953), Sweden (Borg, 1917), Ireland (Toner, 1967), Great Britain (Knight-Jones P., Knight-Jones E.W., 1977), Brittany, France (L'Hardy, Quievreux, 1964), and north-western Spain (Rioja, 1923). In the Arctic $S$. (S.) tridentatus was recorded from the Norwegian, Barents, and White Seas (Aleksandrov, 1981; Jakovis, 1997; Rzhavsky, 1992; Rzhavsky et al., 2014).

Ecology. The species occupies stones and shells from low intertidal zone up to $30 \mathrm{~m}$ deep; usually found under stones and in rock crevices. Juveniles occasionally may be found on algae.

\section{Tube morphology of species not cov- ered with the SEM study}

Four species of the tribe Spirorbini (Spirorbis $(S$.) infundibulum Harris et Knight-Jones E.W., 1964, S. (S.) placophora Bailey et Harris, 1968, Spirorbis (S.) spatulatus Knight-Jones, 1978 and $S$. ( V.) gesae Knight-Jones et KnightJones, 1995) are not covered in the present study. All of them have relatively thin-walled white opaque tubes with coil diameters up to 1.5-2 mm. Appearance of the surface (porcellaneous or non-porcellaneous) is unclear from literature.

S. (S.) spatulatus (Fig. 12A) usually has dextral, but sometimes sinistral planospiral tubes with distinct narrow median keels, but the crosssection remains circular (Knight-Jones P., 1978). Such tubes are not known for any other Spirorbis species.

Two remaining species of the subgenus Spirorbis are sinistral. Tube of $S$. (S.) placophora was never figured in the literature. According to the original description (Bailey, Harris, 1968), this species has a planospiral unsculptured tube circular in cross-section, somewhat similar to the tubes of $S$. ( $S$.) inornatus and $S$. (S.) spirorbis, which are, however, almost twice larger. Tube of $S$. (S.) infundibulum (Fig. 12B) is unsculptured and circular in cross-section, with irregularly overlapping coils and sometimes evoluted last coil (Harris, Knight-Jones E.W., 1964). Among studied Spirorbini only $S$. $(S$.) corallinae may have tubes with overlapping coils, but they overlap regularly. $S$. ( $V$.) gesae (Fig. 12C) has dextral tubes especially similar in external morphology and size to those of $S$. (S.) bifurcatus, however, the latter may be both dextrally or sinistrally coiled. The sculpture of $S$. ( $V$.) gesae is represented by two longitudinal keels, one running towards the periphery and one on the inner edge of the whorl, making the

Fig. 11. Spirorbis (Spirorbis) tridentatus. A-C — tubes: A,B - adult tubes with three massive keels; C juvenile specimens with yet undeveloped sculpture, attached to an adult; D-I — tube ultrastructures: D general view of the transverse section; E - details of the innermost part of the wall showing thick inner organic lining; F — details of the outer part of the wall, note penetration of outer SPHP layer into the main IOP layer along certain growth lines; $\mathrm{G}$ - details of the middle part of the wall; $\mathrm{H}$ - longitudinal section through the coils area contact, general view; I — contact zone and internal wall of the later coil, internal wall has unilayered IOP structure.

Abbreviations: os - outer surface, is - inner surface, wi - tube wall on the internal side of the last coil, we - tube wall on the external side of the next to last coil.

Рис. 11. Spirorbis (Spirorbis) tridentatus. А-С - трубки: А, В - трубки взрослых особей с тремя массивными килями; C - ювенильные особи без скульптуры, прикреплённые к трубке взрослой особи; D-I - ультраструктуры трубок: D - общий вид стенки в поперечном сечении; E- внутренняя часть стенки с толстой органической мембраной; F — наружная часть стенки со сферулитовой призматической структурой, проникающей вглубь стенки вдоль отдельных линий роста; $\mathrm{G}$ - средняя часть стенки; H - продольное сечение через смыкание оборотов, общий вид; I - стенка внутренней стороны позднего оборота и зона смыкания оборотов, внутренняя стенка позднего оборота однослойная и имеет структуру хаотически ориентированных призматических кристаллов.

Условные обозначения: os - наружная поверхность, is - внутренняя поверхность, wi - стенка внутренней стороны позднего оборота; wе - стенка наружной стороны раннего оборота. 

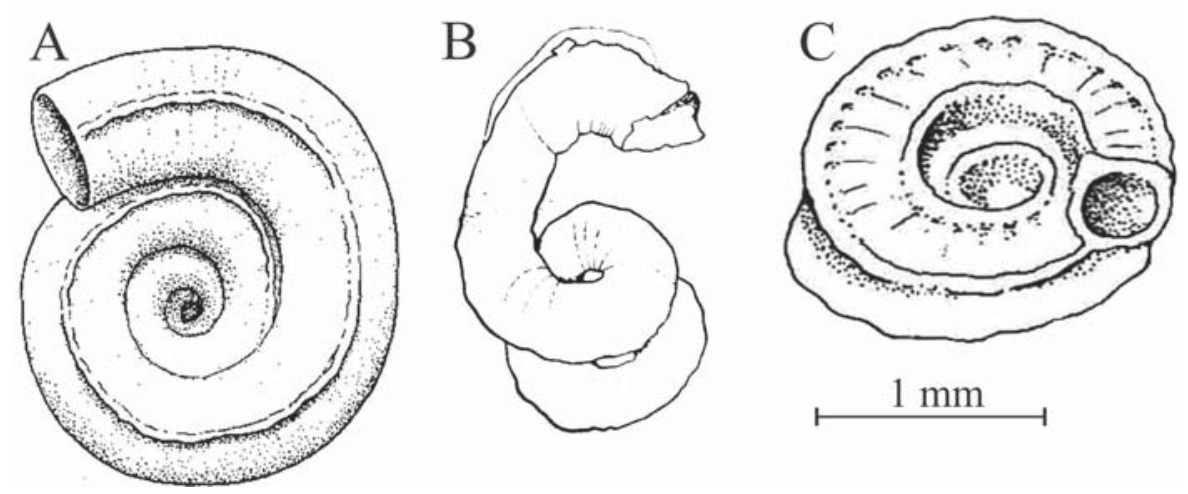

Fig. 12. Tubes of Spirorbini species not covered in the present study. A - Spirorbis (Spirorbis) spatulatus (from Knight-Jones P., 1978, Fig. 3A); B — Spirorbis (Spirorbis) infundibulum (from Harris, Knight-Jones E.W., 1964, Fig. a); C — Spirorbis (Velorbis) gesae (from Knight-Jones P., Knight-Jones E.W., 1995, Fig. 1). Рис. 12. Морфологическое разнообразие трубок представителей Spirorbini, которые не изучались авторами в ходе настоящего исследования. А — Spirorbis (Spirorbis) spatulatus (из Knight-Jones, 1978, Fig. 3A); В — Spirorbis (Spirorbis) infundibulum (из Harris, Knight-Jones, 1964, Fig. a); C — Spirorbis (Velorbis) gesae (из Knight-Jones, Knight-Jones, 1995, Fig. 1).

tube cross-section subquadrangular (KnightJones P., Knight-Jones E.W., 1995).

\section{Discussion}

Remarks to the "Spirorbis spp." ultrastructures described in literature. Spirorbini has the largest record of described ultrastructures (see Weedon, 1994; Taylor, Vinn, 2006), mainly because the name "Spirorbis" is often used as a "wastebin" for any members of the subfamily. Two of these records provided for $S$. ( $S$.) cf. rupestris (see Weedon, 1994) and $S$. (S.) spirorbis (see Sanfilippo, 1998) are discussed above. Recent "Spirorbis sp." figured by Taylor and Vinn (2006: Fig. 1D) with typical IOP ultrastructure called "microstructure of disordered rods" looks identical to certain Spirorbis species described below as Group A and therefore, its assignment within Spirorbis sensu stricto looks probable. The systematic position of five other specimens of "Spirorbis spp." ranging from Pliocene to recent (Taylor, Vinn, 2006: suppl. data list), which have been only reported as having "fine-grained" structures, is not clear.

Patterns and variations. The studied species of the genus Spirorbis are not uniform in their ultrastructures and mineralogy, and can be subdivided into three groups by several correlated characters (Table 1).
Group A includes $S$. (S.) bidentatus, $S$. (S.) bifurcatus, $S$. (S.) cuneatus, $S$. (S.) marioni and $S$. (S.) strigatus. All these species are characterized by predominantly aragonitic (aragonite content $65-90 \%$ ) unilayered tubes with IOP structure and crystals about 3-4 $\mu \mathrm{m}$ long (smaller only in S. cuneatus), not densely consolidated by cement. Macroscopically, all members of Group A typically have subquadrangular tubes with 2 longitudinal keels (additional $3^{\text {rd }}$ median keel may be present) and non-porcellaneous tube surface. The common coiling direction is sinistral (clockwise), but two species (S. bifurcatus and S. marioni) have tubes coiled in both directions. Largest coil diameter within this group does not exceed $2 \mathrm{~mm}$.

Group B, which includes $S$. ( $S$.) corallinae, $S$. (S.) inornatus, $S$. (S.) rupestris, $S$. (S.) spirorbis and $S$. (S.) tridentatus, is characterized by purely calcitic tubes, usually with high $\mathrm{Mg}$ content. Two species, $S$. (S.) spirorbis and $S$. (S.) tridentatus, had doubtful aragonite content not exceeding $23 \%$. However, more reliable analysis of tube sets in both species has shown no aragonite, thus indicating that aragonite content could have been produced by some occasional allogenic carbonate fragments. Ultrastructurally, all members of Group B have outer SPHP layer, while the main IOP layer usually has crystals of comparatively smaller size than those 
Tube morphology, ultrastructures and mineralogy in recent Spirorbinae. II.

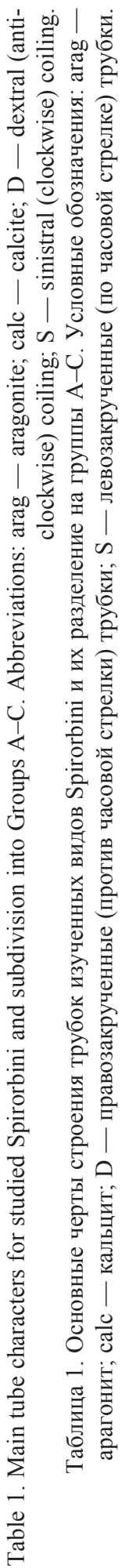

\begin{tabular}{|c|c|c|c|c|c|c|c|c|c|c|c|c|}
\hline \multirow{4}{*}{ 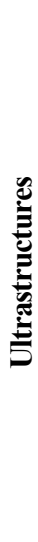 } & 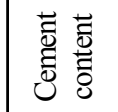 & 蒙 & 올 핼을 & 䒠 & 욜 & 음 & . 맬 & .몰 & .몰 & .맬 & .50 & $\underline{z}$ \\
\hline & 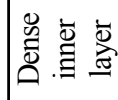 & 1 & 1 & 1 & 1 & 1 & 1 & 1 & 1 & 1 & 1 & 竞 \\
\hline & 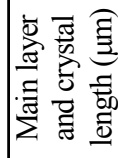 & ô & ô & $\tilde{o} \sim$ & อి " & $\tilde{O}$ & $\stackrel{\circ}{ } \sim$ & $\tilde{\varrho} \sim$ & 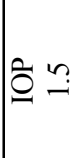 & $\stackrel{0}{0} \sim$ & 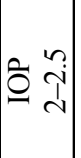 & oิ m \\
\hline & 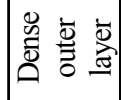 & 1 & 1 & 1 & I & 1 & 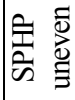 & 昙 & 竞 & 吾 & 害 & 言 \\
\hline \multirow[t]{2}{*}{30} & 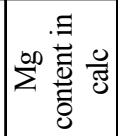 & $\stackrel{z}{0}$ & $\underline{\Xi}$ & $\stackrel{z}{0}$ & 孞 & $\stackrel{z}{0}$ & . कू & . & . & 吕 & 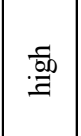 & 宐 \\
\hline & 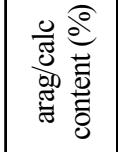 & $\frac{n}{n}$ & 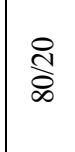 & $\frac{n}{\sqrt[n]{6}}$ & $\stackrel{\circ}{\stackrel{2}{\circ}}$ & 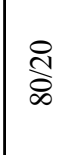 & $\stackrel{8}{3}$ & $\frac{8}{3}$ & $\frac{8}{8}$ & $\frac{8}{3}$ & $\stackrel{8}{\frac{8}{8}}$ & $\frac{8}{1}$ \\
\hline \multirow{5}{*}{ 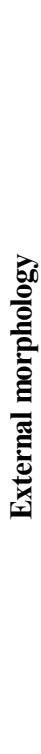 } & 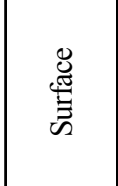 & 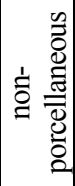 & 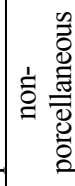 & 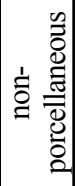 & $\frac{\mathscr{0}}{\stackrel{0}{0}}$ & & 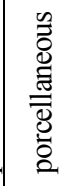 & 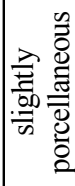 & 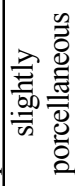 & 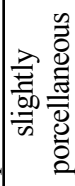 & 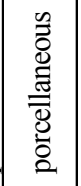 & 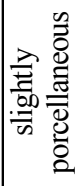 \\
\hline & 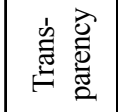 & 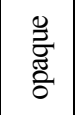 & $\begin{array}{l}\frac{0}{\tilde{\sigma}} \\
\frac{\tilde{\sigma}}{\sigma}\end{array}$ & 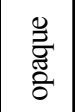 & 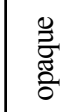 & $\begin{array}{l}\frac{0}{\tilde{z}} \\
\frac{\tilde{z}}{0}\end{array}$ & 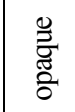 & $\begin{array}{l}\frac{0}{\tilde{E}} \\
\text { ôt }\end{array}$ & 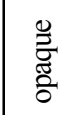 & 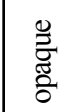 & 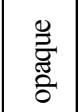 & $\begin{array}{l}\frac{\mathscr{v}}{\tilde{z}} \\
\text { ơ }\end{array}$ \\
\hline & 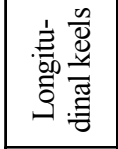 & $\underset{\sim}{(\mathbb{C}}$ & $\sim$ & $m$ & $N$ & 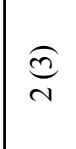 & 0 & 0 & 0 & 0 & 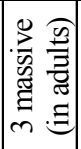 & 0 \\
\hline & 曾 & $\infty$ & 倣 & 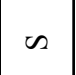 & $\stackrel{\infty}{*}$ & $\sim$ & is & is & Us & Us & in & D \\
\hline & 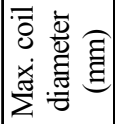 & 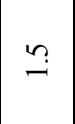 & $\stackrel{n}{\stackrel{n}{I}}$ & $N$ & - & $\stackrel{n}{n}$ & ?n & $m$ & $\stackrel{\sim}{f}$ & $\nabla$ & $\ddot{n}$ & $N$ \\
\hline & $\begin{array}{l}\frac{\mathscr{c}}{8} \\
\text { के }\end{array}$ & 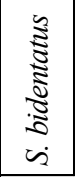 & 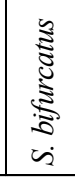 & 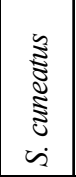 & 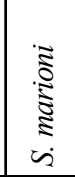 & 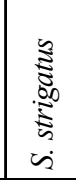 & 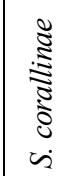 & 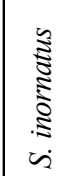 & 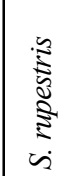 & 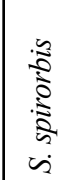 & 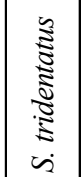 & 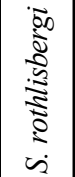 \\
\hline & ثَّ & & & 4 & & & & & $ص$ & & & U \\
\hline
\end{tabular}

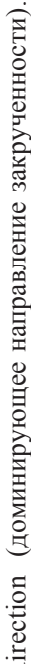

$\stackrel{00}{:}$

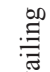


found in Group A (length not exceeding $2 \mu \mathrm{m}$; only $S$. tridentatus was found to have larger crystals), and larger content of cement. Macroscopically, tubes are always sinistral, unsculptured (except for adults of $S$. (S.) tridentatus bearing three massive keels), and with porcellaneous surface. The tube size is larger than in the members of Group A as adult coil diameter is usually $\sim 3-4.5 \mathrm{~mm}$; the only exception is $S$. (S.) corallinae which has coil diameter not exceeding $1.5 \mathrm{~mm}$, however, this species tends to grow upwards rather than planospirally, therefore, its coil diameter is not indicative of its true size.

Group C includes a single species, $S$. $(S$.) rothlisbergi. It has $100 \%$ calcitic tube, like Group B, and crystals in main IOP layer, closer to Group A by shape and size. However, it differs from both from Groups A and B by the presence of thick inner SPHP layer in addition to the outer one. Unsculptured tubes make this species essentially similar to Group B, but it is characterized by obligatory dextral coiling that is not known for Group B and found only in Group A. By the tube size $S$. (S.) rothlisbergi is again closer to Group A.

Among species not covered in this study, $S$. $(V$.) gesae has external morphology characters typical for Group A, while $S$. (S.) placophora and $S$. (S.) infundibulum are closer to Group B. Position of $S$. $(S$.) spatulatus is not clear.

It should be mentioned that SPHP outer layers in some species of Group B $(S$. $(S$.) corallinae, S. (S.) spirorbis, $S$. (S.) tridentatus) are distributed unevenly throughout the surface, and the cement content can vary significantly. Therefore, a reliable differentiation between groups A and B based on ultrastructures is possible only after several sections are studied. Also, crystal size tends to increase in later coils for both main Groups (A and B).

Comparison with other Spirorbinae. Spirorbini tubes belonging to all three groups (A-C) are easily distinguishable from members of the tribe Paralaeospirini (see Ippolitov, Rzhavsky, 2014). Members of the Spirorbini Group A, despite having identical unilayered tubes with IOP structure, are predominantly aragonitic, while Paralaeospirini have purely calcitic tubes. Also, tubes of Spirorbini Group A normally having 2 or 3 keels are hardly comparable with those of Paralaeospirini that are either unsculptured or have a single median keel. The only exception is Paralaeospira sicula Knight-Jones et Knight-Jones, 1994 having quadrangular cross-section similar to that of Spirorbini of Group A. Spirorbini belonging to Groups B and C, despite being essentially similar by external morphology (unsculptured tubes) and mineralogy (pure calcite) to Paralaeospirini, have dense outer (and inner for Group C) SPHP layer, which is absent in Paralaeospirini.

Correlation of tube mineralogy, ultrastructures, and external morphology. Porcellaneous appearance of the tube surface correlates with the presence of the outer layer having SPHP structure (Table 1). This agrees well with the observation that fully transparent tubes have unilayered tubes with simple prismatic (SP) structure (Ippolitov, Rzhavsky, 2008; Vinn et al., 2008) that is essentially similar to SPHP structure. However, within the tribe Paralaeospirini having unilayered walls with IOP structure porcellaneous surface in certain species (e.g., Paralaeospira malardi Caullery et Mesnil, 1897) seems to be well-explained not by the presence of SPHP covering layer, like in Spirorbini, but by dense consolidation of the outermost zone by abundant cement (Ippolitov, Rzhavsky, 2014: 304, Fig. 3A-F).

Mineralogical composition of Spirorbini tubes is well-correlated with ultrastructures. Species of Spirorbini with predominantly aragonitic tubes (Group A) all have unilayered tubes with IOP structure, while species with calcitic tubes (Groups B and C) have covering layer(s) with SPHP structure. This pattern is concordant with the general pattern that SP/ SPHP structures are associated with predominantly calcitic mineralogy (compare mineralogical and ultrastructural data in Vinn et al., 2008; Ippolitov et al., 2014); however, covering SPHP layer was once found to be aragonitic in case of non-spirorbin serpulid Hydroides dianthus (Verrill, 1873) (Tanur et al., 2010).

Interpretation of subdivision into $A-C$ Groups. The difference among members of Group A, B, and C, supported by morphological, ultrastructural, and mineralogical characters, suggests that these groups probably represent individual clades within Spirorbis, the hypothesis that should be verified by further molecular and morphological investigations. 
Biogeographically all members of Group B are known from North Atlantic temperate or temperate and arctic waters. Group A includes tropical and subtropical species from NorthEast Atlantic ( $S$. (S.) cuneatus, S. (S.) strigatus), from North-East Pacific ( $S$. (S.) bifurcatus) and probably invasive species of North Pacific origin widely distributed over the World Ocean $(S$. (S.) bidentatus, $S$. ( $S$.) marioni). The single member of Group C $(S$. ( $S$.) rothlisbergi) is known from off California coast only (NorthEast Pacific). All species included into Groups $\mathrm{A}$ and $\mathrm{C}$ seems to be warm-water and sometimes can reach low-boreal regions (like $S$. (S.) bifurcatus and $S$. (S.) cuneatus). This means that at least the members of Spirorbini with predominantly aragonitic tubes (Group A) are found in warmer habitats, while members of Group B with calcitic tubes inhabit colder environments. The only species of Group C, $S$. (S.) rothlisber$g i$, does not fit this trend. The observation roughly supports the idea of Lowenstam (1954), who observed tubes of tropical serpulid species to be predominantly aragonitic, while those from higher latitudes to be made of calcite-aragonite mixture. This observation was later contested by Bornhold and Milliman (1973) and Smith et al. (2013). However, the members of the tribe Paralaeospirini that have purely calcitic tubes (Ippolitov, Rzhavsky, 2014), like Spirorbini of the Group B, are biogeographically restricted to the Notal (or Austral) belt and thus, again fit the trend suggested by Lowenstam (1954). At the same time, the individual variations within certain species contradict this general trend, as shown by Chan et al. (2013) who observed positive correlation of calcite/aragonite ratio with temperature in non-spirorbin serpulid $\mathrm{Hy}$ droides elegans (Haswell, 1883). The authors also showed that in Hydroides elegans development of outer SPHP layer seems to be environmentally influenced and correlates with high water temperatures (Chan et al., 2013). This observation is not supported by our data on Spirorbis, as members of the genus with developed SPHP layer (Group B) are generally restricted to colder environments than those without SPHP layer (Group A). The obvious correlations of morphological, mineralogical, and structural characters indicates that, in case of Spirorbini, the role of environmental factor for the structure is far less important than that of phylogenetic relationships. Yet, predominantly calcitic serpulids (Hydroides elegans (Haswell, 1883), see Bornhold, Milliman, 1973) may have fully aragonitic juvenile tubes (Chan et al., 2015), probably reflecting evolutionary transitions within the certain phyletic lines and thus supporting the hypothesis that aragonitic mineralogy is the plesiomorphic for the whole family (Vinn, Mutvei, 2009).

An observation that amorphous matter content in Hydroides elegans shows negative correlation with temperature (Chan et al., 2013), generally agrees with our data on Spirorbini (IOP structure of warm-water Groups A and C has low cement content, while relatively coldwater Group B always demonstrates high cement content).

Phylogenetic implications. Early growth stages of tubes in both Groups A and B have IOP structure with almost isometric crystals cemented by abundant amorphous matter. Such structures made of isometric crystals are almost unknown for recent serpulids (Vinn et al., 2008: Tab. 2), despite were described for fossils (e.g., Vinn, Furrer, 2008). Such structures are very close to hypothetical plesiomorphic ultrastructures of Serpulidae consisting of unoriented isometric crystals (Vinn, 2013) and are convergently similar to ultrastructures of early metazoan tubular fossils, such as Cloudina, characterized by primitive biomineralization system (Feng et al., 2003; Vinn, Zatoñ, 2012).

Unlike members of the tribe Paralaeospirini (Ippolitov, Rzhavsky, 2014), many Spirorbini have dense outer layer (DOL sensu Vinn, Kupriyanova, 2011) with SPHP structure. Such feature has been found mostly in clade AI of Serpulidae (sensu Kupriyanova et al., 2009, see Vinn, Kupriyanova, 2011), which includes genera Crucigera Benedict, 1887, Hydroides Gunnerus, 1768, Serpula Linnaeus, 1758 and Spiraserpula Regenhardt, 1961, and has also been recorded in some species of clade AII (e.g., Spirobranchus kraussi (Baird, 1865), see Vinn, Kupriyanova, 2011: Tab. 1). Both clades AI and AII are phylogenetically distant from the subfamily Spirorbinae (Kupriyanova et al., 2006, 2009; Kupriyanova, Nishi, 2010). On the other hand, clade BI (sensu Kupriyanova, Nishi, 2010) which is a sister-group of Spirorbini, does not have covering SPHP layers. Therefore, SPHP 
structure either evolved independently both in spirorbins and non-spirorbin serpulids of clade $\mathrm{A}$, as a result of an adaptation to similar environmental selective pressure, or a combination of main IOP and covering SPHP layers is plesiomorphic for all Serpulidae, while the absence of SPHP layers in Clade BI is a result of secondary simplification.

Recently Chan et al. (2015) have shown that SPHP structure in recent serpulid Hydroides elegans appears significantly later in ontogeny than IOP structure and thus was interpreted as appearing later in evolution. However, it is still not indicative whether last common ancestor of non-spirorbin serpulids and spirorbins already had the combination of both SPHP and IOP structures or not. To date there are no data to support one hypothesis over another.

Outer SPHP layer in Spirorbinae can hardly be interpreted as an adaptation to predation pressure, as suggested for relatively shallowwater serpulids of Clade A (Vinn, Kupriyanova, 2011), because SPHP layer in spirorbins is too thin to provide a good protection. We suppose that in the case of Spirorbinae generally adapted for settlement on ephemeral substrata, such as algae, and inhabiting high-energy environments of sublittoral and littoral zones (Ippolitov, 2010; Ippolitov et al., 2014), the main significance of SPHP covering layer could be mechanical consolidation of the tube walls protecting against mechanical abrasion. This well agrees with the hypothesis of Chan et al. (2015), who supposed that outer SPHP layer may be important for preventing crack propagation on the juvenile tubes of Hydroides elegans, having thick main layer with IOP structure, like we observed in Spirorbini.

\section{Acknowledgements}

We thank L.T. Protasevich, A.V. Kravtsev, and R.A. Rakitov (Office of Instrumental Analytics, PIN RAS), as well as N.N. Surovenkova (IPEE RAS) and V.L. Kosorukov (GF MSU) for their kind help with the technical part of the study. We also thank specialists and institutions who donated materials to the collection of A.V. Rzhavsky (see Ippolitov, Rzhavsky, 2014). We are grateful to E.K. Kupriyanova (Australian Museum Research Institute) and Olev Vinn
(University of Tartu, Estonia), who reviewed the manuscript and provided invaluable remarks and suggestions, greatly improving the paper. Our special thanks are also to E.K. Kupriyanova for her kind help with English. The investigation was supported by the RFBR grant No. 14-0531413 and RAS Presidium Program No. 28.

\section{References}

Aleksandrov D.A. 1981. [Families of polychaete worms (Polychaeta)] // D.A. Naumov, A.V. Olenev (eds.). Zoologicheskie Ekskursii na Belom more [Zoological excursions on the White Sea]. Leningrad: LGU Press. P.85-95, 139-143 [in Russian].

Bailey J.H., Harris M.P. 1968. Spirorbinae (Polychaeta: Serpulidae) of the Galapagos Islands // Journal of Zoology. Vol.155. No.2. P.161-184.

Baird W. 1865. Description of several new species and varieties of tubicolous Annelides = tribe Limivora of Grube, in the collection of the British Museum. Part 1 // Journal of the Linnean Society of London. Vol.8. P.10-22.

Benedict J.E. 1887. Descriptions of ten species and one new genus of annelids from the dredging of the U.S. Fish Commission Steamer Albatross // Proceedings of the United States National Museum.Vol.9. P.547553.

Bergan P. 1953. The Norwegian species of Spirorbis (Daudin) // Nyt Magasin for Zoologi. Vol.1. P.27-48.

Bianchi C.N. 1981. Policheti Serpuloidei. Guide pu il riconoscimento delle specie animali delle acque lagunari e costiere italianie. Genoa. $187 \mathrm{p}$.

Borg F. 1917. Über die Spirorbisarten Swedenes nebst einem Versuch zu einer neuen Einteilung der gattung Spirorbis // Zoologiska bidrag från Uppsala. Vol.5. P.15-38.

Bornhold B.D., Milliman J.D. 1973. Generic and environmental control of carbonate mineralogy in serpulid (polychaete) tubes // Journal of Geology. Vol.81. No.3. P.363-373.

Caullery M., Mesnil F. 1897. Études sur la morphologie comparée et la phylogénie des espèces chez les Spirorbes // Bulletin scientifique de la France et de la Belgique. T.30. P.185-233.

Chamberlin R.V. 1919. The Annelida Polychaeta // Memoirs of the Museum of Comparative Zoology at Harvard College. Vol.48. P.1-514.

Chan V.B.S., Thiyagarajan V., Lu X.W., Zhang T., Shih K. 2013. Temperature dependent effects of elevated $\mathrm{CO}_{2}$ on shell composition and mechanical properties of Hydroides elegans: Insights from a multiple stressor experiment. PLoS ONE. Vol.8. Iss.11. Art.e78945. P.1-11. doi:10.1371/journal.pone.0078945.

Chan V.B.S., Vinn O., Li C., Lu X., Kudryavtsev A.B., Schopf J.W., Shih K., Zhang T., Thiyagarajan V. 2015. Evidence of compositional and ultrastructural shifts during the development of calcareous tubes in the biofouling tubeworm, Hydroides elegans // Journal of Structural Biology. Vol.189. Iss.3. P.230-237. 
Daudin F.M. 1800. Recueil de mémoires et de notes sor des espèces inéditis ou peu connues de mollusques, de vers et de Zoophytes. Paris. 50 p.

Doyle R.W. 1974. Choosing between darkness and light: the ecological genetics of photic behavior in the planktonic larva of Spirorbis borealis // Marine Biology. Vol.25. No.4. P.311-317.

Feng W., Chen Z., Sun W. 2003. Diversification of skeletal microstructures of organisms through the interval from the latest Precambrian to the Early Cambrian // Science in China (Series D). Vol.46. No.10. P.977-985.

Gee J.M. 1964. The British Spirorbinae with a description of $S$. cuneatus sp. n., and a review of the genus Spirorbis // Proceedings of the Zoological Society of London. Vol.143. No.3. P.405-441.

Gee G.M., Knight-Jones E.W. 1962. The morphology and larval behavior of a new species of Spirorbis (Serpulidae) // Journal of the Marine Biological Association of the United Kingdom. Vol.42. No 3. P.641-654.

Gunnerus, J. 1768. Om nogle norske coraller // Dek Korgelize Norske Videnskabens Selskab Trondhjem Skrifter. T.4. P.38-73.

Hardy J.-P., L', Quievreux C. 1962. Remarques sur le polymorphisme de Spirorbis borealis Daudin // Comptes Rendus de l'Académie des Science, Paris. Vol.255. No.17. P.2173-2175.

Hardy J.-P., L', Quievreux C. 1964. Observations sur Spirorbis (Laeospira) inornatus (Polychete Serpulidae) et sur la systematique de s Spirorbinae // Cahiers de Biologie Marine. Vol.5. No.3. P.287-294.

Harris T. 1968. Spirorbis species (Polychaeta: Serpulidae) from the Isles of Scilly, including descriptions of two new species // Journal of the Marine Biological Association of the United Kingdom. Vol.48. No.3. P.593602.

Harris T., Knight-Jones E.W. 1964. Spirorbis infundibulum sp. nov. (Polychaeta: Serpulidae) from Tenarea shelves on the Costa Brava // Annals and Magazine of Natural History: Ser.13. Vol.7. No.78. P.347-351.

Haswell W.A. 1883. On some new Australian tubicolous annelids // Proceedings of the Linnean Society of New South Wales. Vol.7. P.633-638.

Ippolitov A.P. 2010. Serpulid (Annelida, Polychaeta) evolution and ecological diversification patterns during Middle-Late Jurassic//Earth Science Frontiers. Vol.17. Special Issue. P.207-208.

Ippolitov A.P., Rzhavsky A.V. 2008. On the tube microstructure of recent spirorbids (Annelida, Polychaeta) // Doklady Biological Sciences. Vol.418. P.20-22.

Ippolitov A.P., Rzhavsky A.V. 2014. Tube morphology, ultrastructures and mineralogy in recent Spirorbinae (Annelida; Polychaeta; Serpulidae). I. General Introduction. Material and methods. Tribe Paralaeospirini // Invertebrate Zoology. Vol.11. No.2. P. 293-314.

Ippolitov A.P, Vinn O, Kupriyanova E.K, Jäger M. 2014. Written in stone: history of serpulid polychaetes through time // Memoirs of Museum Victoria. Vol.71. P.123-159.

Jakovis E.L. 1997. [Preliminary data on the fauna polychaetes worms of the family Spirorbidae (Polychaeta, Sedentaria) of the White Sea] // Anichkovskij vestnik. Vol.1. P.33-54 [in Russian].

Knight-Jones E.W., Knight-Jones P. 1980. Pacific spirorbids in the East Atlantic // Journal of the Marine
Biological Association of the United Kingdom. Vol.60. No.2. P.461-464.

Knight-Jones P. 1978. New Spirorbidae (Polychaeta: Sedentaria) from the East Pacific, Atlantic, Indian and Southern Oceans // Zoological Journal of the Linnean Society, London. Vol.64. No.3. P.201-240.

Knight-Jones P., Knight-Jones E.W. 1977. Taxonomy and ecology of British Spirorbidae (Polychaeta) // Journal of the Marine Biological Association of the United Kingdom. Vol.57. No.2. P.453-499.

Knight-Jones P., Knight-Jones E.W. 1984. Systematics, ecology and distribution of Southern Hemisphere spirorbids (Polychaeta: Spirorbidae) // P.A. Hutchings (ed.). Proceedings of the First International Polychaete Conference, Sydney: Linnean Society of N.S.W Press. P.197-210.

Knight-Jones P., Knight-Jones E.W. 1994. Spirorbidae (Polychaeta) from Signy Island, South Orkneys, including three new species // Ophelia. Vol.40. No.2. P.75-94.

Knight-Jones P., Knight-Jones E.W. 1995. Spirorbidae (Polychaeta) from Madeira including a new species and subgenus of Spirorbis // Mitteilungen aus dem Hamburgischen zoologischen Museum und Institute. Vol.92. P.89-101.

Knight-Jones P., Knight-Jones E.W., Buzhinskaja G.N. 1991. Distribution and interrelationships of Northern spirorbid genera // Bulletin of Marine Science. Vol.48. No.2. P.189-197.

Knight-Jones P., Knight-Jones E.W., Dales R.P. 1979. Spirorbidae (Polychaeta: Sedentaria) from Alaska to Panama // Journal of Zoology. Vol.189. No.4. P.419458.

Kohn A.J., Lloyd M.C. 1973. Marine polychaete annelids of Easter Islands // Internationale Revue der gesammten Hydrobiologie. Vol.58. No.5. P.691-712.

Kupriyanova E.K., Macdonald T.A., Rouse G.W. 2006. Phylogenetic relationships within Serpulidae (Sabellida, Annelida) inferred from molecular and morphological data // Zoologica Scripta. Vol.35. P.421439.

Kupriyanova E.K., Nishi E. 2010. Serpulidae (Annelida, Polychaeta) from Patton-Murray Seamount, Gulf of Alaska, North Pacific Ocean // Zootaxa. Vol. 2665. P.51-68.

Kupriyanova E.K., Hove H.A. ten, Sket B., Zakšek V., Trontelj P., Rouse G.W. 2009. Evolution of the unique freshwater cave-dwelling tube worm Marifugia cavatica (Annelida: Serpulidae)// Systematics and Biodiversity. Vol.7. No.4. P.389-401.

Levinsen G.M.R. 1884. Systematisk-geografisk oversight over de nordiske Annulata, Gephyrea, Chaetognathi, og Balanoglossi // Videnskabelige Meddelelser fra Dansk naturhistorisk Forening i Kjøbenhavn. 1882. P. $160-251$

Linnaeus C. [as Linné C.] 1758. Systema Naturae per regna tria naturae, secundum classes, ordines, genera, species, cum characteribus, differentiis, synonymis, locis. Laurentius Salvius, Holmiae. $10^{\text {th }}$ ed. 824 p.

Lowenstam H.A. 1954. Environmental relations of modification compositions of certain carbonate secreting marine invertebrates // Proceedings of the National Academy of Sciences of the United States of America. Vol.40. P.39-48. 
Regenhardt H. 1961. Serpulidae (Polychaeta Sedentaria) aus der Kreide Mitteleuropas, ihre ökologische, taxonomische und stratigaphische Bedeutung // Mitteilungen aus dem Geologischen Staatsinstitut in Hamburg. Hft.30. S.5-115.

Rioja E. 1923. Estudio sistemático de las especies Ibéricas del suborden Sabelliformia // Trabajos del Museo Nacional de Ciencias Naturales Serie Zoológica. Vol.48. P.5-144.

Rzhavsky A.V. 1992. [A review of Circeinae and Spirorbinae (Polychaeta, Spirorbidae) of the Russian seas with description of the new species Circeis gurjanovae] // Zoologicheskij Zhurnal. Vol.71. No.7. P.5-13 [in Russian].

Rzhavsky A.V. 2001. Spirorbidae // I.A. Jirkov (ed.). Polichety Severnogo Ledovitogo okeana [Polychaeta of the Arctic Ocean]. Moscow: Yanus-K Press. P.572606 [in Russian].

Rzhavsky A.V., Kupriyanova E.K., Sikorski A.V., Dahle S. 2014. Calcareous tubeworms (Polychaeta, Serpulidae) of the Arctic Ocean. Moscow: KMK Scientific Press. $191 \mathrm{p}$.

Sanfilippo R. 1998. Spirorbid Polychaetes as boreal guests in the Mediterranean Pleistocene // Rivista Italiana di Paleontologia e Stratigrafia. Vol.104. Nî.2. P.279286.

Silva P.H.D.H., de, Knight-Jones E.W. 1962. Spirorbis corallinae $\mathrm{n}$. $\mathrm{sp}$. and some other Spirorbinae (Serpulidea) common on British shores // Journal of the Marine Biological Association of the United Kingdom. Vol.42. No.3. P.601-608.

Smith A.M., Riedi M.A., Winter D.J. 2013. Temperate reefs in a changing ocean: skeletal carbonate mineralogy of serpulids // Marine Biology. Vol.160. P.22812294. doi: 10.1007/s00227-013-2210-Z

Tanur A.E., Gunari N., Sullan R.M.A., Kavanagh C.J., Walker G.C. 2010. Insights into the composition, morphology, and formation of the calcareous shell of the serpulid Hydroides dianthus // Journal of Structural Biology. Vol.169. P.145-160.

Taylor P.D., Vinn O. 2006. Convergent morphology in small spiral worm tubes ('Spirorbis') and its palaeoenvironmental implications // Journal of the Geological Society (London). Vol.163. P.225-228.

Toner P. 1967. An ecological study of the genus Spirorbis (Serpulidae) on the east coast of Ireland // Scientific Proceedings of the Royal Dublin Society. Ser.A. Vol.2. No.20. P.319-330.

Uchida H. 1978. Serpulid tube worms (Polychaeta, Sedentaria) from Japan with a systematic review of the group // Bulletin of the Marine Park Research Stations. Vol.2. P.2-98.

Verrill, A.E. 1873. Report upon the invertebrate animals of Vineyard Sound and the adjacent waters, with an account of the physical characters of the region // United States Commission of Fisheries, Washington. Report for 1871-1872. P.295-778.

Vine P.J. 1977. The marine fauna of New Zealand: Spirorbinae (Polychaeta: Serpulidae) // New Zealand Oceanographic Institute Memoir. Vol.68. P.1-66.

Vine P.J., Bailey-Brock J.H., Straughan D. 1972. Spirorbinae (Polychaeta, Serpulidae) of the Hawaiian Chain. Part 2. Hawaiian Spirorbinae// Pacific Science. Vol.26. No.2. P.150-182.

Vinn O. 2013. SEM study of semi-oriented tube microstructures of Serpulidae (Polychaeta, Annelida): implications for the evolution of complex oriented microstructures // Microscopy Research and Technique. Vol.76. P.453-456.

Vinn O., Furrer H. 2008. Tube structure and ultrastructure of serpulids from the Jurassic of France and Switzerland, its evolutionary implications // Neues Jahrbuch für Geologie und Paläontologie, Abhandlungen. Vol.250. No.2. P.129-135.

Vinn O., Kupriyanova E.K. 2011. Evolution of a dense outer protective tube layer in serpulids (Polychaeta, Annelida) // Carnets de Géologie [Notebooks on Geology]. Letter CG2011/05 (CG2011_L05).

Vinn O., Mutvei H. 2009. Calcareous tubeworms of the Phanerozoic // Estonian Journal of Earth Sciences. Vol.58. No.4. P.286-296.

Vinn O., Zatoñ M. 2012. Inconsistencies in proposed annelid affinities of early biomineralized organism Cloudina (Ediacaran): structural and ontogenetic evidences // Carnets de Géologie [Notebooks on Geology]. Article 2012/03 (CG2012_A03). P.39-47.

Vinn O., Hove H.A. ten, Mutvei $\bar{H}$., Kirsmäe K. 2008. Ultrastructure and mineral composition of serpulid tubes (Polychaeta, Annelida) // Zoological Journal of the Linnean Society. Vol.154. P. 633-650.

Weedon M.J. 1994. Tube microstructure of recent and Jurassic serpulid polychaetes and the question of the Paleozoic spirorbids // Acta Palaeontologica Polonica. Vol.39. No.1. P.1-15.

Woelkerling W.J., Irvine L.M. 1986. The typification and status of Phymatolithon (Corallinaceae, Rhodophyta) // British Phycological Journal. Vol.21. No.1. P.5580.

Zibrowius H., Bianchi C.N. 1981. Spirorbis marioni et Pileolaria berkeleyana, Spirorbidae exotiques dans les ports de la Méditerranée nord-ocidentale // Rapport de la Commission de l'Exploration de la mer Méditerranée, Monaco. Vol.27. No.2. P.163-164.

Responsible editors E.N. Temereva, K.G. Mikhailov 